DIW BERLIN

Discussion Papers
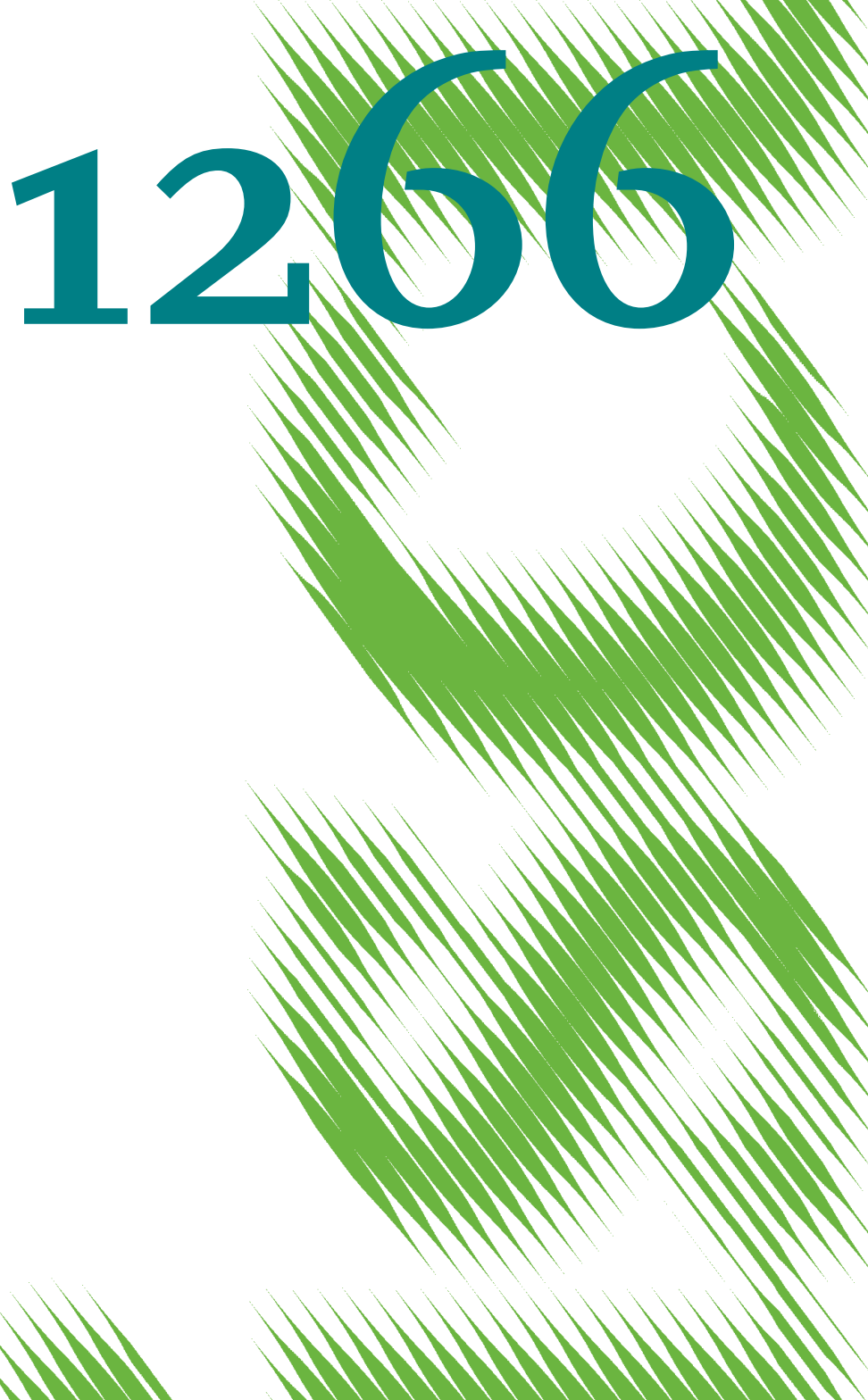

MMMMMMMMMTH

Religious Heterogeneity and Fiscal Policy

Evidence from German Reunification 
Opinions expressed in this paper are those of the author(s) and do not necessarily reflect views of the institute.

IMPRESSUM

(C) DIW Berlin, 2013

DIW Berlin

German Institute for Economic Research

Mohrenstr. 58

10117 Berlin

Tel. $+49(30) 89789-0$

Fax +49 (30) $89789-200$

http://www.diw.de

ISSN print edition $1433-0210$

ISSN electronic edition 1619-4535

Papers can be downloaded free of charge from the DIW Berlin website:

http://www.diw.de/discussionpapers

Discussion Papers of DIW Berlin are indexed in RePEc and SSRN:

http://ideas.repec.org/s/diw/diwwpp.html

http://www.ssrn.com/link/DIW-Berlin-German-Inst-Econ-Res.html 


\title{
RELIGIOUS HETEROGENEITY AND FISCAL POLICY: EVIDENCE FROM GERMAN REUNIFICATION*
}

\author{
Ronny Freier Benny Geys Joshua Holm
}

January 28, 2013

\begin{abstract}
Theoretical work based on social identity theory and in-group favoritism predicts that increased population diversity (e.g., due to immigration) reduces support for redistributive public policies. In this article, we add to the empirical literature testing this prediction in three ways. First, rather than ethno-linguistic or racial heterogeneity, we analyze religious diversity, which in many countries is an increasingly important source of diversity. Second, to account for the potential endogeneity of heterogeneity, we analyze an exogenous shock in diversity due to the German reunification. Finally, we assess shifts in local individuals' social identification after immigration took place, which, while untested in previous contributions, is a critical theoretical mechanism. Our results - using tax and spending decisions of 2031 Bavarian municipalities over the 1983-2005 period - indicate that Catholic municipalities in particular significantly reduced their level of taxes and spending in response to non-Catholic immigration. These effects arise only after the first post-reunification local elections, suggesting a critical mediating role of the democratic process.
\end{abstract}

Keywords: $\quad$ local identity, fiscal policy, redistribution, German reunification, diff-in-diff estimation

JEL classification: H10, H11, H77

*Corresponding author: Benny Geys, Norwegian Business School BI, Nydalsveien 37, 0484 Oslo, Tel.: +47 46410923, Email: Benny.Geys@bi.no. We are grateful to Zareh Asatryan, Friedrich Heinemann, Kai Konrad, Ronnie Schöb, Marcel Thum and seminar participants at Vrije Universiteit Brussel (VUB) and the WZB Berlin for insightful comments on a previous version. The usual disclaimer applies. 
"What is the use of the best welfare state, when the communists come" ("Was nützt der schönste Sozialstaat, wenn die Kosaken kommen") Franz Josef Strauss (Bavarian state minister 1978-88).

\section{Introduction}

Immigrants often differ in terms of, say, race, ethnicity, language or religion from the native population of the region in which they settle. Consequently, substantive migration flows tend to alter the composition of a jurisdiction's population and increase its heterogeneity. While such diversity can bring important benefits due to differences in cognitive abilities and problem-solving perspectives across different types of people (e.g., Hong and Page, 2004; Alesina and La Ferrara, 2005), it may also put substantial strain on redistributive public policies. Roemer et al. (2007) suggest that the latter effect operates through political parties: i.e., parties favoring stricter immigration rules generally tend to support smaller welfare states as well. Alesina et al. (1999) and Alesina and La Ferrara (2000), however, build on social identity theory (e.g., Tajfel and Turner, 1986) to propose a micro-level transmission mechanism based on individuals' preferences. Specifically, if individuals are more altruistic towards those with whom they share a common 'identity,' they "may attribute positive utility to the well-being of members of their own group and negative utility to that of members of other groups" (Alesina and La Ferrara, 2005, 765). As a result, a community will be less likely to provide redistributive public goods when diversity is higher. More recently, Shayo (2009) and Lindquist and Östling (2013) provide more extensive theoretical models linking individuals' positions regarding redistributive taxation to their social identities.

Previous empirical work evaluating this prediction has strongly concentrated on race, language and, especially, ethnicity as indicators of socio-demographic distinctions between individuals (e.g., Alesina et al., 1999; Habyarimana et al., 2007; Jofre-Monseny 
et al., 2011; Dahlberg et al., 2012; for a review, see Stichnoth and Van der Straeten, 2013). Yet, group identification need not be defined solely or predominantly in terms of ethnicity. The first contribution of this article, therefore, is to focus on religious diversity, which is becoming an increasing source of social cleavage in regions throughout the world. This shift in focal point not only allows investigating the extent to which earlier findings carry over to other sources of heterogeneity, but also provides insights into the potential consequences of the increasing religious diversity of many countries, regions, and localities.

Our second contribution is related to the identification of the heterogeneity-redistribution relation. Socio-demographic heterogeneity is generally not independent from local fiscal policies because migrants' location decisions are influenced by 'sorting' (Tiebout, 1956). Moreover, the threat of migration itself could trigger a decrease in public good provision when communities try to make themselves less attractive to (welfare) migrants. This creates a crucial endogeneity concern, which may invalidate the causal nature of inferences obtained from cross-sectional analyses (e.g., Alesina et al., 1999; Habyarimana et al., 2007). To address this concern we rely on the exceptional event of the German reunification. This event has three characteristics which provide the means to construct a compelling identification strategy.

First, German reunification presents us with a discrete moment in time after which communities in the former West Germany were suddenly subject to mobility from states of the former East Germany, as well as to immigration by ethnic Germans originating elsewhere in the former Soviet Bloc. (Throughout, we refer to the latter group simply as ethnic Germans.) This migration shock can reasonably be treated as exogenous because reunification happened both quickly and abruptly, as well as being widely unanticipated (Fuchs-Schuendlen and Schuendlen, 2005; Alesina and FuchsSchuendlen, 2007; Buchardi and Hassan, 2011). Second, ethnic Germans - though not East Germans - were subject to a placement program, implying that at least part 
of the change in immigrant shares at the local level constitutes exogenous variation (see Dahlberg et al., 2012, for a similar argument). Finally, a very large majority of immigrants was not Catholic. While this substantially affected the religious homogeneity of previously predominantly Catholic municipalities, it had a much more limited effect on religious diversity in municipalities with no Catholic plurality. To exploit such variation, we concentrate on the 2031 municipalities in the West German state of Bavaria. This state not only shares a border with (former) East Germany (making it subject to large immigration after reunification), but also had substantial variation in the concentration of Catholic inhabitants at municipal level prior to reunification (which provides the opportunity to compare municipalities according to their degree of pre-reunification religious homogeneity in a difference-in-differences estimation approach). ${ }^{1}$

Analyzing the tax and spending decisions of 2031 Bavarian municipalities over the 1983-2005 period, we find that increasing religious diversity matters strongly for local public policies. Municipalities which were religiously more homogeneous (i.e. Catholic) prior to reunification recorded significantly slower growth in both public revenues and expenditures following (predominantly non-Catholic) immigration in the post-reunification period compared to municipalities which were already more religiously diverse. On the revenue side, these observations are largely driven by a lesser relative reliance on property taxation (especially on non-agricultural land) and fees in ex ante religiously homogeneous municipalities, while grant revenue continued to develop in similar fashion across both subsets of municipalities (which is reasonable given the allocation formulas behind such grants). On the expenditure side, we uncover substantially lower expenditure on public utilities, administration and social welfare (including adult education programs and child care provisions) in ex ante religiously homogeneous municipalities in the post-reunification period.

\footnotetext{
${ }^{1}$ From a more practical viewpoint, Bavaria also has local-level fiscal information available for a long time span covering the period before the fall of the Wall.
} 
As a third contribution, we are the first to include an explicit assessment of the central mechanism driving the heterogeneity-redistribution relation in the theoretical framework by Alesina et al. (1999) and Alesina and La Ferrara (2000): i.e. reduced preferences for redistributive fiscal policies in increasingly heterogenous environments are driven by individuals' lesser altruism towards those with whom they do not share a common 'identity' (see above). Particularly, we evaluate to what extent identification with one's town of residence is affected by substantial immigration. In line with the theoretical model proposed by Alesina et al. (1999) and Alesina and La Ferrara (2000), we find that reported identification with one's town of residence weakened substantially among Catholic, but not Protestant, inhabitants of Bavaria between 1991 and 2008. Hence, following the post-reunification inflow of predominantly nonCatholic immigrants, Catholics in Bavaria indeed appear to have lost their feeling of 'common identity' with their fellow inhabitants at the local level to a substantially greater degree than Protestant Bavarians.

Finally, it appears that our main fiscal effects gain traction only after 1996. This appears a relatively long incubation period, and might call into question the interpretation offered above. However, Bavarian municipalities' first local elections after the reunification migration wave only took place in March 1996, and we show that voters appear to have seized these elections as an opportunity to signal changing preferences to incumbent politicians. Moreover, a legislative reform made it possible to organize local referenda on public policies (including, but not restrictecd to, fiscal matters) as of October 1995. As shown by, among others, Pommerehne (1978) and Matsusaka (2004, 2005), referenda or other direct democratic measures tend to tilt public policy closer to the median voter's position. Romer and Rosenthal (1979) and Gerber (1996) even show that citizen initiatives need not reach the ballot, since merely the threat of a potential direct democratic measure may already alter the actions taken by policymakers. Consequently, this legislative reform is likely to have had a sig- 
nificant impact on local public policies after 1996 (which arguably became less in favor of redistributive fiscal policies in ex ante Catholic towns witnessing substantial non-Catholic immigration).

The remainder of the paper is structured as follows. Section 2 introduces the data employed in the empirical analysis. Then, section 3 discusses the empirical strategy, while section 4 brings together our main findings. Conclusions are presented in section 5.

\section{Data and descriptive statistics}

To address the heterogeneity-redistribution relation, we have built a panel dataset covering all 2031 municipalities in Bavaria for the years from 1983 - 2005 (thus including the time before and after reunification in 1989). ${ }^{2}$ Our focus on municipal data derives from the fact that this constitutes the lowest of the four German governmental tiers, and provides a large set of observations working within a homogeneous institutional context. Moreover, municipal governments in Germany have a wide range of spending responsibilities. Besides being involved in welfare services such as local child care provision and education, they also bear responsibility for cultural events, sport and recreational facilities, local infrastructure investments and various other minor tasks. Furthermore, they often supervise local public firms (water and energy supply) and administer spending allocated from higher tiers. Local government revenues mainly derive from three sources: allocated grants, taxes and fees. Among the taxes, municipalities are free to set three local tax rates independently: the property tax A on agriculture land, the property tax $\mathrm{B}$ on all other land and the local trade (business) tax. Key descriptive statistics with respect to these fiscal outcome data are provided in table $\mathrm{X}$ in the appendix.

\footnotetext{
${ }^{2}$ Throughout the analysis, we exclude the very largest cities (the most populous municipality retained in the sample has under 52000 inhabitants) as these may differ fundamentally in their susceptibility to heterogeneity effects.
} 
We restrict our attention to the southern (West) German state of Bavaria since, in relation to the other former West German Länder it has three key features which make it particularly valuable for our analysis. First, Bavaria shares a border with the former East Germany, and its municipalities therefore saw massive migration by East Germans and ethnic Germans following reunification in 1989. In addition to its proximity to the former East, Bavaria's economic strength attracted to it a substantial share of post-reunification migrants to the West. ${ }^{3}$ Figure I shows that the year 1989 indeed saw a sharp change in the development of the Bavarian population. While population growth had been nearly stagnant before 1989, the average municipality in Bavaria grew about 10 percent in population in the period 1989-1995 (see the upper panel of figure I). Much of this population increase was concentrated in larger (than average) municipalities. In the lower-left panel of figure I, we show that municipalities below 4000 inhabitants saw little to no population growth, whereas larger municipalities in the lower-right panel of figure I saw substantial growth (about 18 percent from 1989-1995). We exploit this division below to assess the robustness and validity of our results.

Figure I here

Second, Bavaria has historically been characterized by a predominantly Catholic population. This is important as a very large majority of the immigrants in the reunification-induced migration wave was not Catholic. Consequently, reunification migration affected the religious composition of the Bavarian population. To highlight the difference in the religious denomination of the newcomers, table I presents the religious denominations of Bavarians, East Germans and ethnic Germans surveyed in the German SOEP (Socio-Economic Panel). This shows that a large majority of Bavarians in 1990 were indeed Catholic (i.e., just under 65 percent). In comparison,

\footnotetext{
${ }^{3}$ Still today, Bavaria receives more than one fourth of all Germans who migrate from eastern states to the former West (see Granato and Niebuhr, 2009).
} 
East Germans in that same year were predominantly non-religious or Prostestant. While ethnic Germans were more religious in general, here too a smaller share was Catholic than was true of Bavaria's population (i.e., about 53 percent). Comparing columns 2 and 3 also indicates that the East Germans who migrated were broadly similar in religious make-up to those who did not migrate. This lends support to the argument, important for our identification strategy, that religion was not a primary determinant in the migration decisions of typical East and ethnic Germans.

\section{Table I here}

Finally, although the Bavarian population was predominantly Catholic, substantial variation in the shares of religious denominations remained evident across municipalities within the state. Hence, non-Catholic immigration substantially affected the religious homogeneity of municipalities which were initially predominantly Catholic, while it had a much more limited effect on religious diversity in municipalities with no Catholic plurality. Consequently, we build our identification strategy on the comparision of towns which were religiously homogeneous or non-homogeneous before the reunification migration wave (see section 3 for details). To measure this historical local-level religious heterogeneity, we extract information on the shares of religious denominations in each Bavarian municipality from the 1987 census. As highlighted in table II, we use this information to calculate different measures of pre-reunification heterogeneity. As our main variable, we compute the Herfindahl-Hirschman-Index (HHI) based on the shares of all religious denominations (including non-believers as one group). In the data, the average HHI is 0.741 , which indicates that the average Bavarian municipality was indeed very homogeneous in religious confession before reunification. As an alternative, we also define an indicator variable which takes the value one when Catholics represent the plurality of inhabitants. Although most of the municipalities in Bavaria in 1987 were predominantly Catholic, there is a consider- 
able share (17.1 percent) of communities with non-Catholic (and de facto Protestant) pluralities.

Table II here

\section{Empirical Strategy}

Our empirical model rests on a simple difference-in-difference design, whereby we compare ex ante religiously homogeneous to ex ante religiously heterogenous municipalities before and after reunification. Several authors have previously made use of the German reunification as a natural experiment to strengthen causal inferences (for instance, Fuchs-Schuendlen and Schuendlen, 2005; Alesina and Fuchs-Schuendlen, 2007; Redding and Sturm, 2008; Buchardi and Hassan, 2011). In line with such contributions, our identification strategy exploits the migration wave triggered by the German reunification. Indeed, as a consequence of the German reunification, about 3.4 million former East Germans migrated into the West between 1989 and 2005. Although many East Germans eventually migrated back and some West Germans chose to migrate into the former East (mainly Berlin), net migration from East to West is estimated at about 2 million people (see Wolff, 2007). Additionally, about 2 million ethnic Germans decided to migrate to (mainly West) Germany from the states of the former Eastern Bloc. Crucially, this migration shock can reasonably be treated as exogenous since reunification was widely unanticipated.

Whereas reunification thus provides the first 'difference' for our difference-in-difference estimation approach (i.e., before/after 1989), the second 'difference' derives from the comparison of ex ante religiously homogeneous to ex ante religiously heterogenous municipalities. This is driven by the fact that a very large majority of immigrants was not Catholic (see above), and the reunification migration wave substantially affected 
the religious homogeneity of predominantly Catholic municipalities, but had a much more limited effect on religious diversity elsewhere. In other words, the 'treatment' given by reunification to municipalities in Bavaria differed depending on their ex ante degree of religious homogeneity, which we exploit to identify the effect of increased religious heterogeneity on (local) fiscal policies.

Naturally, the fall of the Wall implied many changes for people across Germany. Municipalities often experienced economic changes following the addition of the new German states. Redding and Sturm (2008), for instance, have argued that firms - and thus municipalities' finances - benefited from the change in access to new markets. Also, it is easily imagined that reunification changed the tax competition environment, at least for those Western municipalities close to the border. We would therefore expect changes in municipalities' fiscal measures following reunification for a multitude of reasons. Proper identification of the effect we are interested in thus requires the following assumptions. First, both religiously homogeneous and heterogenous municipalities are ex ante similar in the trend in fiscal policy variables (common trend assumption). Second, the unexpected shock of reunification affects religiously homogeneous and heterogenous municipalities similarly except for the channel of social identity and in-group favoritism. We will provide evidence below (see section 4) in support of both the common trend assumption, the effect of reunification migration on social identification, and the fact that other influences - e.g. the above-mentioned access to market or tax competition considerations - are likely to have been similar across all municipalities in Bavaria, irrespective of local identity status.

Our central regression equation reads as follows:

$$
Y_{i, t}=\alpha+\beta_{1} \text { Heterog }_{i, t} * \text { Post }_{t}+\beta_{2} \text { Heterog }_{i, t}+\beta_{3} \text { Post }_{t}+X_{i, t} \gamma+z_{t}+\epsilon_{i, t} .
$$


where the outcome variables $Y_{i, t}$ for municipality $i$ in year $t$ are indicators of local fiscal policy such as total expenditures, disaggregated spending and revenue categories, and the property and trade tax multipliers. The coefficient of interest is $\beta_{1}$ on the interaction of the variable measuring ex ante religious heterogeneity, Heterog, and the dummy indicating the post-1989 years, Post. We also include a number of control variables in $X_{i, t}$. Specifically, we carefully control for population size differentials, which may induce differential effects in fical policies, by introducing linear and quadratic measures of population size. Also, we interact those population controls with the post-reunification dummy to allow for different size effects before and after the fall of the Wall. As a further precaution, we also include a number of population group dummies which control for the fact that municipalities in certain size classes have different responsibilities (see Ade and Freier, 2011). Lastly, we include a complete set of year dummies in all specifications.

As discussed with respect to table II, we use two alternative specifications for the variable measuring ex ante religious heterogeneity, Heterog. First, we specify an indicator variable equal to one if the HHI of religious diversity in the municipality in 1987 is above the median of the HHI distribution. Alternatively, we specify an indicator variable taking the value one if the municipality has a plurality of Catholic inhabitants. For both definitions, we experiment with the precise cutoff between both groups in the robustness section.

Clearly, however, for identification based on towns' diverging pre-reunification religious heterogeneity to be valid, it is necessary that those towns are distributed throughout Bavaria (and not simply clustered in two groups) and face similar levels of migration. The first issue is illustrated in figure III in the appendix, where we provide maps of the spatial distribution of religious heterogeneity in 1987 across Bavaria. Despite some degree of clustering in the east of Bavaria (something we return to when testing the robustness of our results), large parts of Bavaria have homogeneous and 
non-homogeneous towns side by side. The second issue is illustrated in figure IV in the appendix, where we show that populations grew quite uniformly in Catholic and non-Catholic municipalities (see lower panels; all for larger municipalities). The same holds for municipalities in the northern and southern part of Bavaria (see upper panels; all for larger municipalities). This similarity in part reflects the placement of immigrating ethnic Germans throughout the country without concern to geography or religion.

\section{Empirical findings}

\subsection{Main Results}

We estimate equation 1 using three different specifications: i.e. OLS as well as models incorporating random and fixed effects for municipalities. Our main results - using total expenditures (per capita and per year) as the outcome variable - are presented in tables III and IV. The sole difference between the two tables is that table III relies on the HHI to distinguish municipalities in terms of their religious concentration in 1987, whereas table IV employs a plurality of Catholics as the binary treatment. To preserve space, both tables present only the coefficient of interest on the interaction term between the dummy for homogeneous/heterogenous towns and the post-1989 dummy. Columns 1-3 show the results of OLS, random effects and fixed effects models, respectively, for a model without control variables. In columns 4-6, we additionally control for the influence of population size as explained above.

In both tables III and IV, all specifications show similar negative coefficient estimates for the interaction variable. Point estimates range between -94 Euro and -134.1 Euro per capita in table III, and between -119.6 Euro and -139.5 Euro per capita in table IV. All these estimates are significant at the 5 percent level or better. Since expenditures trended upward throughout the sample period, these results indicate 
that ex ante highly concentrated (and hence religiously homogeneous) municipalities had a significantly slower increase in total spending per capita and year after the reunification. This supports the idea that the disruption of social identity in Bavarian Catholic towns following the German reunification induced significantly depressed public spending (we return to this disruption of social identity below). Focusing on our preferred specifications (provided in column 6 of both tables), the effect represents a sizable relative difference of almost 9 percent in the level of expenditures (i.e., 133.1 Euro to 135.4 Euro on an average yearly budget of 1520 Euro per capita).

Table III here

Table IV here

In table $\mathrm{V}$, we exploit the fact that significant migration occurred only to larger municipalities (i.e. with more than 4000 inhabitants; see lower panels of figure I) to implement a first validity check. This specific migration pattern indeed implies that our results should be significantly more powerful in the sample of larger towns which have thus far been used. If, however, our results are driven by factors related to towns' Catholic pluralities but unrelated to the migration wave post 1989, we would expect to find similar shifts among the small municipalities which witnessed very little immigration. To verify this, we include all small municipalities (i.e. under 4000 inhabitants) in our estimation sample, and implement a difference-in-difference-indifference model (with town size as the third 'difference'). As table V indicates, the difference between ex ante religiously homogeneous and heterogenous towns observed above is strongly driven by the larger towns which actually saw substantial migration - a finding which holds for both measures of religious heterogeneity. Figure $\mathrm{V}$ in the appendix presents this observation visually. The spending level in larger towns (left panel) clearly diverges between Catholic and non-Catholic towns while no similar 
divergence is observed in smaller towns (right panel). This substantiates the idea that post-reunification migration is driving our results.

\section{Table V here}

In table XI in the appendix, we provide a more detailed analysis of the expenditure effects by examining three different spending categories (columns 1 to 3 ), and also turn to the revenue side of the budget (columns 4 to 6 ). To preserve space, we report only the results from our preferred specification including municipality fixed effects and detailed population controls. Panel 1 again relies on the HHI to separate homogeneous and heterogenous towns, while panel 2 employs the dummy variable indicating a plurality of Catholics. The results illustrate that both spending on personnel and operating expenditure are particularly restrained in ex ante highly homogeneous communities in response to the wave of migration. Investment spending, however, is unaffected by the migration wave and retains a similar level across both types of municipalities even after 1989. With regard to revenues, we find that tax and fee revenues become significantly lower in towns with ex ante high homogeneity (compared to ex ante heterogenous towns), but that there is no significant effect on grant revenues. The latter is reassuring, as grants are mainly allocated through pre-defined formulas and thus should not depend on town-specific homogeneity. Table XII in the appendix further substantiates these results, by showing that local tax rates have indeed witnessed a relatively slower increase in ex ante highly concentrated towns after reunification (compared to ex ante heterogenous towns). Note that the findings here are statistically strongest for the property tax B on non-agricultural land, but vary for the other tax rates in terms of significance depending on the exact definition of the measure of homogeneity.

Finally, table XIII in the appendix addresses the fact that the spending categories in table XI remain rather broad, and is based on more detailed expenditure data we 
collected for all municipalities over the period of 1998-2005. Unfortunately, earlier data on this level of disaggregation are unavailable, which prevents us from using our difference-in-difference design here. Nevertheless, as is also highlighted in figure V, spending levels of towns with and without an ex ante Catholic plurality were similar before the reunification, so a comparision based on later years' raw differences in detailed spending components is still informative. In examining these differences, we find that towns with ex ante Catholic pluralities and more than 4000 inhabitants spend significantly less on general administration, public utilities (such as water, electricity and gas), adult education and child care. With the exception of public utilities, we find none of those effects to be significant in smaller municipalities, which saw effectivey no migration. These findings indicate that the ex ante Catholic towns which saw the highest levels of (predominantly non-Catholic) migration implemented a strong relative reduction in spending, particularly on policies which tend to benefit immigrants (i.e. adult education and child care). In similar vein, we find no difference in spending on elderly care, an expenditure category which is more likely to affect "natives" relative to new migrants. Also, we find no significant difference in spending on public order (after including detailed controls for population differences) and significantly higher spending on churches. The latter suggests that at least part of the public funds in ex ante Catholic towns were re-allocated after reunification from policies potentially benefiting non-Catholic migrants towards policies certainly favoring Catholic "natives." 4

Before turning to the robustness checks, we note that the massive migration wave following reunification appears to have affected individuals' social identification, particularly in ex ante Catholic Bavarian towns. This is important because - even though this generally remains untested in previous work - the Alesina et al. (1999) and Alesina

\footnotetext{
${ }^{4}$ Generally, municipalities in Germany bear no responsibility to finance churches. Churches already receive direct tax support from the (substantial) church tax on all income. However, municipalities are free to voluntarily support local churches.
} 
and La Ferrara (2000) framework argues that lower preferences for redistribution in heterogenous communities are driven by individuals feeling a higher degree of altruism towards those with whom they share a common 'identity.' To test this, we analyzed data on the strength of individuals' identification with their home town and its inhabitants from the German ALLBUS surveys. ${ }^{5}$ While such data are, unfortunately, available only for 1991 and 2008, this nonetheless allows us to illustrate the change in such attitudes among Catholic and Protestant Bavarians after reunification. This is presented in figure II, which reports the marginal effect of being Catholic on the propensity to feel strongly attached to one's home town and its inhabitants. ${ }^{6}$ Figure II clearly illustrates that there was no significant difference in the strength of identification of Catholics and Protestants in Bavaria in 1991 (though with Catholics feeling slightly more attached on average), but that Catholics were significantly less likely to strongly identify with their communities in 2008, after the reunification migration wave (statistically significant at 10 percent). Catholics in Bavaria thus appear to have lost their feeling of 'common identity' with their fellow inhabitants at the local level to a substantially larger degree than Protestant Bavarians, which - in the Alesina et al. (1999) and Alesina and La Ferrara (2000) framework - would underpin their lower preference for redistributive fiscal policies. Interestingly, West German Catholics outside of Bavaria - who were less strongly subjected to non-Catholic immigration after reunification - show the opposite pattern (with a weakly stronger local attachment after reunification).

Figure II here

\footnotetext{
${ }^{5}$ The exact phrasing of the question is: Regarding your emotional connection to your town and its inhabitants, do you feel strongly connected, quite connected, little connected, or not at all connected? (Sind Sie Ihrer Gemeinde und ihren Bürgern gefühlsmässig stark verbunden, ziemlich verbunden, wenig verbunden oder gar nicht verbunden?).

${ }^{6}$ This marginal effect is derived from a simple ordered logit regression with social identification to one's town and its inhabitants as the dependent variable and an indicator variable for Catholics as the main independent variable. Controls for an individual's income level, education level, political leaning and town size are included. Detailed results available upon request.
} 


\subsection{Robustness checks}

The robustness of our findings is first tested in table VI. In column 1, we exclude 23 Bavarian municipalities which saw closures of US military bases after reunification. Because the closure of these bases presents a unique and often substantial shock to the local economy of those municipalities, one might wonder whether these events affect our results. In column 2 , we include a variable measuring the distance to the town's closest local urban center (i.e. county-free cities or Kreisfreie Städte). There are 25 such cities in Bavaria, and the concern may be that those cities showed a differential trend in economic growth after reunification. Moreover, the distance to the town's closest local urban center can also serve as a proxy for a town's own urban/rural character, and thus allows controlling for the fact that homogeneous and heterogenous towns may differ in the extent of their urban character. ${ }^{7}$ Next, in column 3 , we exclude two regions in the east of Bavaria along the Czech border. These, as indicated in the maps in figure III, not only tend to be more religiously homogeneous, but also fell under a subsidy scheme (Zonenrandförderung) before reunification which was meant to support public activities in areas close to the countries of the Warsaw Pact. ${ }^{8}$ In column 4, we include region-specific time trends to capture the possibility that regions with a different degree of ex ante religious homogeneity have seen differential trends in their economic activity after reunification. Finally, in columns 5 and 6 , we separate the sample into towns which saw above-median and below-median population growth in the period 1995-2005. This controls for the possibility that the persistently greater immigration in ex ante Catholic towns after 1995 (see figure IV) is driving our results, since we now compare only towns with comparable post-1995 growth rates (but diverging ex ante religious heterogeneity). Overall, the results of the first four

\footnotetext{
${ }^{7}$ Our distance measure is calculated as the distance between the geographical center of the municipality to the center of the closest county-free city.

${ }^{8}$ Note that we also estimated models in which we excluded each the seven Bavarian regions one by one to ensure that the results are not driven by municipalities in a single region. Our findings were unafffected (details upon request).
} 
robustness tests show that our main effects remain comparable throughout, and that our findings thus are remarkably stable. The test in columns 5 and 6 demonstrates a particularly strong effect in those towns where immigration and population growth continued at high rates after 1995. The implication that migration-induced changes to the religious composition of a town continue to affect its public policy beyond the immediate reunification period suggests that our results might well have broader applicability.

\section{Table VI here}

In table VII, we further test the robustness of our results with regard to restrictions made on the data. In columns 1 and 2, we test the estimates' robustness to changes in the initial limitations imposed on the data sample. In the original results, we use only municipalities with more than 4000 inhabitants (as it was those which saw massive migration after 1989). In columns 1 and 2 we omit municipalities below the thresholds of 3000 and 5000 inhabitants, respectively. Then, in columns 3 and 4, we exclude certain years from the analysis as it is not clear when the influence of migration should start to take effect. We omit only the year 1989 in column 3 and 1989 as well as 1990 in column 4. Lastly, we experiment with different thresholds in the definitions of the religious homogeneity measures. For the dummy based on the HHI we cut the distribution at the 60th (column 5) and the 70th (column 6) percentiles of the HHI distribution instead of the median. For the dummy indicating Catholic plurality we use redefinitions requiring a Catholic share of more than 50 percent (column 5) as well as more than 66.6 percent (column 6). In all these additional specifications, the results remain significantly negative and comparable to the previous findings.

Table VII here 
Thus far, we have generally compared towns with a Catholic plurality in 1987 to those which had no such plurality. However, the latter group contains both towns which had a fairly even distribution of Catholics and Protestants, and those which were predominantly Protestant. This might affect our findings since non-Catholic (and de facto often Protestant) immigration would - following the predictions from social identity theory - have had a much weaker effect in the latter subgroup. In table VIII, we therefore restrict the sample to include only the non-Catholic towns which are most religiously concentrated (i.e. the 92 out of 183 municipalities which are most concentrated). As we now compare only towns where immigration is likely to have had the strongest effect on fiscal policies (i.e. ex ante homogeneous Catholic towns) with those where this effect is likely to have been weakest (i.e. ex ante homogeneous Protestant towns), this should lead to stronger effects. This is confirmed in table VIII, where the point estimates have increased substantially relative to those reported in section 4.1 .

\section{Table VIII here}

Finally, we also wish to include a measure of economic growth or unemployment to exclude the possibility that our findings are driven by a differential trend in economic growth. This might arise if the above-mentioned access to market (Redding and Sturm, 2008) or tax competition considerations were to affect homogeneous and heterogenous municipalities differently. Unfortunately, data for municipal-level economic growth are unavailable, and unemployment data are available only starting from 1998. As a necessary (but not sufficient) test, we therefore check the difference in the unemployment rates (defined as the number of unemployed over the number of inhabitants) in the period 1998-2004. While ex ante predominantly Catholic towns consistently show a slightly lower unemployment rate compared to ex-ante non-Catholic towns, the trend over time in both groups is very similar (see figure VI in the appendix). Taken 
together with the results including region-specific time trends (see column 4 in table VI), we therefore consider it unlikely that economic factors such as unemployment rates are a driving force behind the observed spending effects.

\subsection{Mediating role of the democratic process?}

Figure $\mathrm{V}$ discussed above clearly underscores the validity of the common trend assumption for our analysis, as it indicates that both Catholic and non-Catholic towns show a similar steady increase in the expenditure level per capita and per year before reunification (i.e. 1983-1988). Still, the same figure also suggests a closer analysis of the exact timing of the changes uncovered in section 4.1. The figure underscores that the expenditure level for both groups remains similar not only before reunification, but also through the early 1990s. It is only from 1996 that the expenditure levels of the two groups start to diverge drastically. This late-period divergence clearly drives the effects observed above. As this appears to be a relatively long incubation period, the question arises as to the reason for the delay.

There are two pieces of evidence indicating that the democratic process might be playing an important mediating role in our German setting, and may explain the long incubation period. First, it was only in March 1996 that the first elections any appreciable interval after the reunification were held for town councils and mayors. The previous elections had been held in March 1990, very shortly after reunification and well before the full extent of migration was realized. The March 1996 elections thus provided voters their first opportunity to signal to local politicians - both incumbents and opposition - changed preferences with respect to local fiscal policies afterthe bulk of the immigration wave had arrived. Supportive of our main results, this possibility appears to have been taken up particularly strongly in ex ante religiously homogeneous towns. This can be seen in table IX, where we provide the results of a difference-in-difference design assessing whether ex ante Catholic and ex 
ante non-Catholic towns show different trends in their election results before and after reunification. ${ }^{9}$ The party which dominated politics in Bavaria both before and after the reunification (i.e. CSU; the Bavarian sister-party to the CDU of current Chancellor Angela Merkel) experienced a significant shock both in terms of its vote and seat share (columns 1 and 2) and its probability of achieving an absolute majority (column 5) in the March 1996 elections. We hypothesize that the reduction in spending which occurs after 1996 in ex ante Catholic-plurality towns may well be a response to that shock by the incumbent CSU party. ${ }^{10}$

Table IX here

The second indication favoring a key mediating role for the democratic process comes from a legislative reform in Bavaria which made it possible to organize local referenda on public policies (including, but not restrictecd to, fiscal matters) as of October 1995. Crucially, the threshold for organizing such referenda was set relatively low: i.e. applications consist only of one Yes/No question to be posed during the referendum, and should be supported by the signatures of three to ten percent of the municipal population (depending on the town's population size; see also Ade and Freier, 2011). Once the municipal council formally approves the referendum, it has to be organized at the municipality's cost within three months. The result has the effect of a decision by the municipality council (subject to a quorum rule which again depends on the size of the municipality), and cannot be changed in the first year except by another

\footnotetext{
${ }^{9}$ For this part of the analysis, we collected data on all local council elections within our time period. Council elections in Bavaria were held in 1984, 1990, 1996 and 2002.

${ }^{10} \mathrm{We}$ should also note at this point that data on party manifestos from the Manifesto Research Group at the WZB Berlin suggest a substantial shift away from active support for the welfare state in the CDU/CSU party programs since the mid 1990s; a trend which the other German parties (SPD and FDP) only followed towards the end of the 1990s. Although these manifestos refer to the national-level parties, this is suggestive of a strong move away from welfare state support following reunification within the main German political parties, which seems to start earliest and develop most strongly in the party dominating local politics in Bavaria. Interestingly, no similar decline can be observed setting in around this time in such other western European countries as Austria, Switzerland or Belgium. Full details are available upon request.
} 
referendum. These low thresholds made referenda a popular instrument in the first years of their availability, with 1371 applications leading to 835 referenda between 1995 and 2005.

The introduction of direct democratic elements into the political decision process in Bavaria is important for our results because direct democracy has often been argued - and shown - to shift enacted public policies nearer to those preferred by the median voter. Bowen (1943), for instance, was the first to observe that sequential up-or-down referendum votes - common in the US for funding social goods such as education - make the level of taxation or expenditure incrementally approach that preferred by the median voter. Passing only when an electoral majority favors the proposed expenditure level to the current level, spending converges to the median preferred rate. More recently, studies comparing local governments with direct democratic and representative political institutions find broad support for the idea that direct democracy causes fiscal and legislative outcomes to more closely reflect the preferences of the electoral majority (e.g., Pommerehne, 1978; Gerber, 1996; Feld and Kirchgässner, 2000; Matsusaka, 2004, 2005; and references therein). Interestingly, referendum or initiative measures need not even reach the ballot before affecting policy. Romer and Rosenthal (1979) and Gerber (1996) illustrate that merely the threat of a potential direct democratic measure may alter the actions taken by policymakers. Consequently, this legislative reform is likely to have tilted public policy after 1996 more in the direction favored by the median voter, who - in ex ante Catholic towns witnessing substantial non-Catholic immigration - arguably became less in favor of redistributive fiscal policies.

\section{Conclusion}

Exploiting insights from social identity theory, Alesina et al. (1999) and Alesina and La Ferrara (2000) argue that a population's willingness to redistribute among its 
members may be decreasing in its heterogeneity because such heterogeneity induces a corrosion of the social fabric of society. Previous empirical work tends to support the former part of this prediction - i.e. a negative heterogeneity-redistribution relationship - but i) restricts attention to linguistic, racial, or ethnic heterogeneity dimensions (for a survey, see Stichnoth and Van der Straeten, 2013) and ii) fails to test the theoretical mechanism - i.e. weakening social identification - underlying this relation.

In this article, we have focused on an increasingly important source of social cleavagenamely, religious heterogeneity - and accounted for the potential endogeneity of locallevel heterogeneity by exploiting the post-reunification immigration shock from East Germany and Eastern Europe in the years following the fall of the Berlin Wall (see Dahlberg et al., 2012, for a similar identification strategy). The results showed that homogeneous, Catholic communities facing substantial, predominantly non-Catholic immigration show slower growth in per capita taxes and public goods expenditures across several revenue and expenditure categories - estimated at approximately nine percent of total expenditures - compared to religiously heterogeneous or Protestant communities facing the same migration wave. The size of these effects is broadly comparable to the effect of ethnic heterogeneity previously analysed. Alesina et al. (1999), for instance, find reductions between 8 and 17 percent in various spending categories in US cities, metropolitian areas and counties due to ethnic heterogeneity, while Jofre-Monseny et al. (2011) show that Spanish municipalities decrease the share of the budget allocated to welfare spending by 16 to 26 percent following massive immigration.

We have also found that, in keeping with social identity theory's concept of targeted altruism, individuals from religiously homogeneous, Catholic towns are likely to have seen immigrants from the East as more different than did individuals from heterogeneous or Protestant towns. This is substantiated by the fact that, relative to Bavarian Protestants, the trend among Bavarian Catholics was toward substantially 
weaker identification with their communities and their fellow inhabitants between 1991 and 2008. This relative weakening in the social identification of inhabitants in religiously homogeneous, Catholic towns due to the inflow of non-Catholic immigrants would make them less inclined to support public policies benefiting this out-group as argued by Alesina et al. (1999) and Alesina and La Ferrara (2000), and observed here.

Finally, the divergence in Catholic and non-Catholic towns' fiscal policies takes hold only several years after the reunification. Nevertheless, this lag closely coincides both with the first local elections to be held any substantial interval after the reunification (in March 1996), and with a new provision for local referenda on public policies (in October 1995). Both elements would be expected to align public policies more closely with the preferences of the local population. In line with such view, we found evidence in local electoral results of Catholic towns holding their incumbent majority to task - much more so than Protestant towns - in the March 1996 municipal elections. Moreover, evidence from party manifestos shows emphasis shifting away from support for the welfare state starting around the mid 1990's - a movement which starts earliest and is most extensive in the party dominating Bavarian local politics. These results strongly suggest that the democratic process is bridging individual preferences and town-level fiscal policy.

At the national level in Germany, the inclusion of the East mattered greatly in the formation of public policy by West German politicians (who kept a near-monopoly on political power well into the early 2000's). The Hartz reforms in the early 2000's, for instance, included massive cutbacks in the generosity of basic social welfare and affected East Germans disproportionately. Our analysis shows a similar pattern arising at the local level, driven by the massive immigration of members of religious 'out-groups' and the ensuing decline in local-level social identification. 


\section{Author affiliation}

Ronny Freier - DIW Berlin and Humboldt University, rfreier@diw.de

Joshua Holm - Vrije Universiteit Brussel, Email: Joshua.Holm@vub.ac.be

Benny Geys - Norwegian Business School BI and Vrije Universiteit Brussel, Email:

Benny.Geys@bi.no

\section{References}

Ade, F. and R. Freier, "Divided Government versus Incumbency Externality Effect: Quasi-Experimental Evidence on Multiple Voting Decisions," DIW Discussion paper, nr. 1121, 2011.

Alesina, A., R. Baqir and W. Easterly, "Public goods and ethnic divisions," Quarterly Journal of Economics, 114 (1999), 1243-1284.

Alesina, A. and E. La Ferrara, "Participation in Heterogeneous Communities," Quarterly Journal of Economics, 115 (2000), 847-904.

Alesina, A. and E. La Ferrara, "Ethnic Diversity and Economic Performance," Journal of Economic Literature, 43 (2005), 762-800.

Alesina, A. and N. Fuchs-Schuendlen, "Goodbye Lenin (or not?): The Effect of Communism on People's Preferences," American Economic Review, 97 (2007), 1507-1528.

Bowen, H., "The interpretation of voting in the allocation of economic resources," Quarterly Journal of Economics, 58 (1943), 27-48.

Burchardi, K.B. and T.A. Hassan, "The Economic Impact of Social Ties: Evidence from German Reunification," mimeo (2011).

Dahlberg, M., K. Edmark and H. Lundqvist, "Ethnic Diversity and Preferences for Redistribution," Journal of Political Economy, 120 (2012), 41-76.

Feld, L.P. and G. Kirchgässner, "Direct democracy, political culture, and the outcome of economic policy: a report on the Swiss experience," European Journal of Political Economy, 16 (2000), 287-306.

Fuchs-Schuendeln, N. and M. Schuendeln, "Precautionary Svaings and Self-Selection: Evidence from the German Reunification 'Experiment'," Quarterly Journal of Economics, 120 (2005), 1085-1120. 
Gerber, E. R., "Legislative response to the threat of popular initiatives," American Journal of Political Science, 40 (1996), 99-128.

Gerber, E. R., The Populist Paradox: Interest Group Influence and the Promise of Direct Legislation (Princeton: Princeton University Press, 1999).

Granato, N. and A. Niebuhr, "Arbeitskrftewanderungen nach Qualifikation: Verluste in Ostdeutschland gehen zurück," IAB-Kurzbericht, 7/2009, 2009.

Habyarimana, J., M. Humphreys, D.N. Posner and J. Weinstein, "Why does ethnic diversity undermine public goods provision?," American Political Science Review, 101 (2007), 709-725.

Hong, L. and S.E. Page, "Groups of Diverse Problem Solvers can Outperform Groups of High-ability Problem Solvers," Proceedings of the National Academy of Sciences, 101(46) (2004), 16385-16389.

Jofre-Monseny, J., P. Sorribas-Navarro and J. Vazquez-Grenno, "Welfare Spending and Ethnic Heterogeneity: Evidence from a Massive Immigration Wave," Institut d'Economia de Barcelona Working Paper, 2011/34, 2011.

Lindquist, E. and R. Östling, "Identity and Redistribution," Public Choice, forthcoming (2013).

Matsusaka, J.G., For the Many or the Few: The Initiative, Public Policy, and American Democracy (Chicago: University of Chicago Press, 2004).

Matsusaka, J.G., "The eclipse of legislatures: Direct democracy in the 21st century," Public Choice, 124 (2005), 157-177.

Pommerehne, W.W., "Institutional approaches to public expenditure: empirical evidence from Swiss municipalities," Journal of Public Economics, 9 (1978), 255-280.

Redding, S.J. and D. Sturm, "The Costs of Remoteness: Evidence from German Division and Reunification," American Economic Review, 98(5) (2008), 1766-1797.

Roemer, J., W. Lee and K. Van der Straeten, Racism, Xenophobia, and Distribution: Multi-issue Politics in Advanced Democracies (Cambridge: Harvard University Press, 2007).

Romer, T. and H. Rosenthal, "Bureaucrats versus voters: On the political economy of resource allocation by direct democracy," Quarterly Journal of Economics, 93 (1979), 563-587. 
Shayo, M., "A Theory of Social Identity with an Application to Redistribution," American Political Science Review, 103(2) (2009), 147-174.

Stichnoth, H. and K. Van der Straeten, "Ethnic Diversity, Public Spending and Individual Support for the Welfare State: A Review of the Empirical Literature," Journal of Economic Surveys, forthcoming (2013).

Tajfel, H. and J.C. Turner, "The social identity theory of inter-group behavior," in S. Worchel and L.W. Austin (eds.), Psychology of Intergroup Relations (Chicago: Nelson-Hall, 1986).

Tiebout, C., "A Pure Theory of Local Expenditures," Journal of Political Economy, 64(5) (1956), 416-424.

Wolff, S., "Prognosen zur Ost-West-Wanderung nach der deutschen Wiedervereinigung," University of Göttingen Discussion Paper No. 132, 2007. 


\section{$6 \quad$ Tables and figures}

Figure I: Yearly changes in population figures for 1984-2005 (in percent)
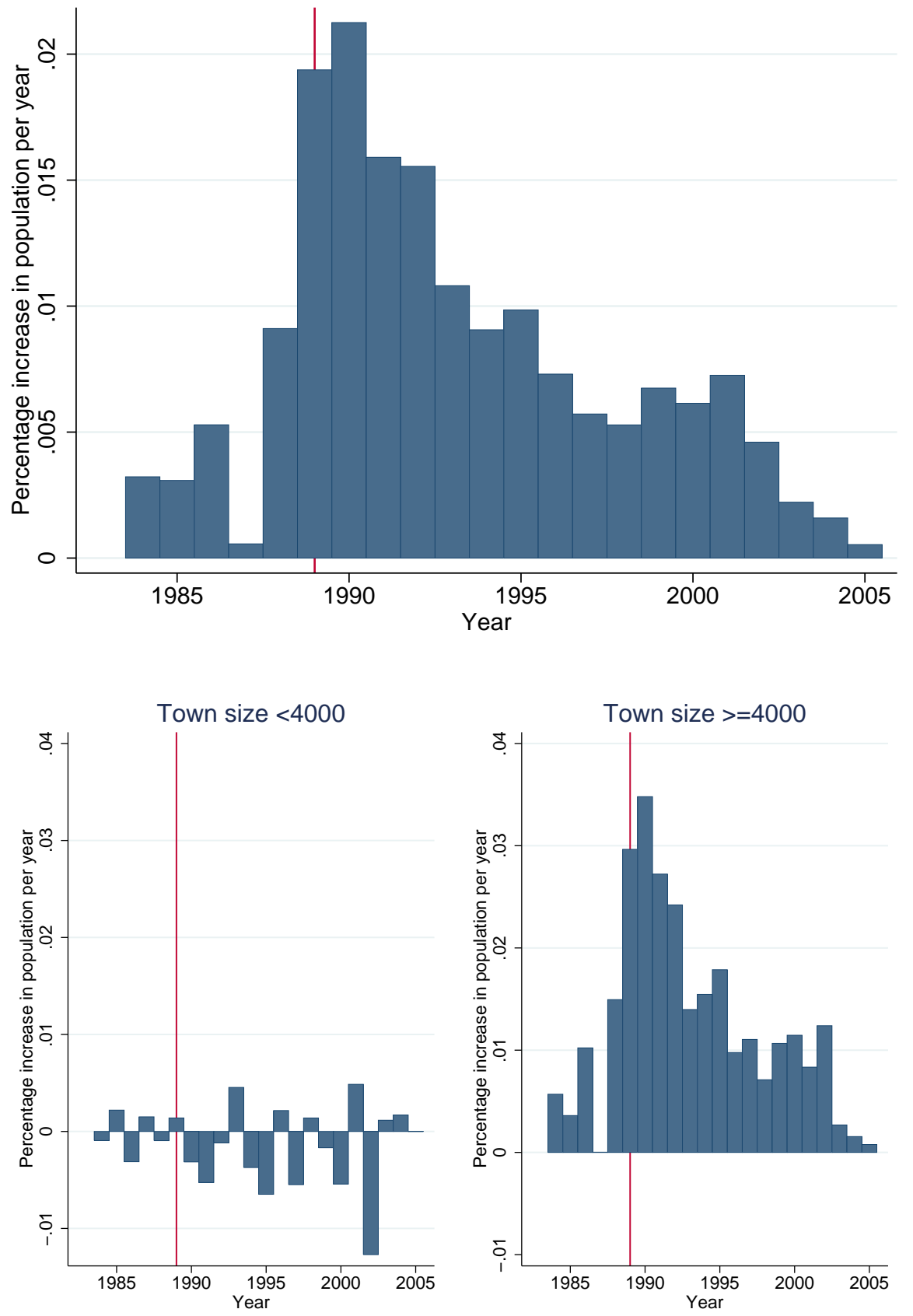

Notes: This figure shows the year-to-year increases in population (in percent) in the period 1984-2005. The upper part of the figure shows the average population growth across all Bavarian municipalities, while the lower part differentiates between municipalities below 4000 inhabitants (the lower-left panel) and above 4000 inhabitants (the lower-right panel). The year 1987 is notably different from other years because there was a general census in which population numbers were corrected. The vertical line indicates the year 1989 in which the reunification process began. Source: Own calculations. 
Table I: Religious denomination of Bavarians, East Germans and migrants

\begin{tabular}{lcccc}
\hline \hline & \multicolumn{4}{c}{ Sample (from GSOEP) } \\
\cline { 2 - 5 } & & & Migrants in the West after 1997 \\
\cline { 2 - 5 } & Bavaria 1990 & East Germany 1990 & East Germans & Ethnic Germans \\
\hline Catholic & 1 & 2 & 3 & 4 \\
Protestant & 64.87 & 6.12 & 5.56 & 52.90 \\
Other Christian religions & 24.76 & 30.46 & 24.10 & 31.90 \\
Other religions & 2.22 & 0.58 & 0.81 & 6.13 \\
No confession & 2.09 & 0.14 & 69.05 & 8.94 \\
\hline
\end{tabular}

Notes: This table presents the religious denominations in respective samples from the German Socio-Economic Panel. The first column presents the shares of particular religions in the sample of the Bavarian population in 1990. In column 2, we show how religion is distributed in the former East in that same year. Columns 3 and 4 highlight the religious composition for the samples of individuals who migrated to the former West Germany. These last samples come from 1997 and later, and are separated into immigrants from the former East (column 3) and ethnic Germans (column 4) who migrated from the former Soviet Bloc.

Table II: Descriptive statistics on town size and religious diversity

\begin{tabular}{lccccc}
\hline \hline \multicolumn{1}{c}{ Variable } & Mean & Std. dev & Median & Min & Max \\
\hline \# of inhabitants & 4105.3 & 4594.6 & 2521 & 186 & 51440 \\
& & & & & \\
Share of Catholics & 0.626 & 0.300 & 0.745 & 0.001 & 0.976 \\
Share of Protestants & 0.114 & 0.225 & 0.009 & 0 & 0.925 \\
Herfindahl-index & 0.741 & 0.143 & 0.769 & 0.369 & 0.976 \\
Towns with Catholic plurality & 0.829 & 0.377 & 1 & 0 & 1 \\
\hline
\end{tabular}

Notes: The table presents key descriptive statistics on the towns in the analysis. We highlight the mean, standard deviation, and median as well as min and max of all variables. The first row gives an indication of town sizes. In the following rows, we provide information on the religious diversity within the municipalities prior to reunification via the share of Catholics, Protestants, the Herfindahl-Hirschman-index (using the share of all religious denominations including nonreligious) and a dummy on whether the town has a plurality of Catholics. Data on religious denominations derives from the 1987 census. Source: Own calculations. 
Table III: Diff-in-Diff comparing highly concentrated to less concentrated towns

\begin{tabular}{lcccccc}
\hline \hline & \multicolumn{7}{c}{ Total spending } \\
\cline { 2 - 7 } & OLS & RE & FE & OLS & RE & FE \\
\hline Interaction & 1 & 2 & 3 & 4 & 5 & 6 \\
Post 89 ${ }^{*}$ high HHI & $-94.0^{* *}$ & $-96.6^{* * *}$ & $-96.7^{* * *}$ & $-122.2^{* *}$ & $-134.1^{* * *}$ & $-133.1^{* * *}$ \\
& $(42.8)$ & $(20.8)$ & $(20.8)$ & $(49.1)$ & $(21.9)$ & $(22.0)$ \\
\hline Pop controls & & & & yes & yes & yes \\
Year effects & yes & yes & yes & yes & yes & yes \\
N & 14427 & 14427 & 14427 & 14427 & 14427 & 14427 \\
R2 & 0.10 & & 0.17 & 0.11 & & 0.18 \\
\hline
\end{tabular}

Notes: Significance levels: ${ }^{*} p<0.10,{ }^{* *} p<0.05,{ }^{* * *} p<0.01$. Robust standard errors in parentheses. The table shows the results from a difference-in-difference regression analysis. The outcome variable is yearly total expenditure per capita. The parameter of interest is the interaction between a dummy indicating that the observation is post 1989 and a dummy indicating that the municipality was relatively religiously homogeneous in 1987 (i.e., the HHI is above the median). The first three columns present regressions in which we control only for year fixed effects, while we include detailed population controls in the latter three specifications. In columns 1 and 4 we use simple OLS, in 2 and 5 we specify a random effects model and in 3 and 6 we include municipality fixed effects. Source: Own calculations.

Table IV: Diff-in-Diff comparing towns with Catholic plurality to non-Catholic towns

\begin{tabular}{lcccccc}
\hline \hline & \multicolumn{7}{c}{ Total spending } \\
\cline { 2 - 7 } & OLS & RE & FE & OLS & RE & FE \\
\hline Interaction & 1 & 2 & 3 & 4 & 5 & 6 \\
Post 89 ${ }^{*}$ Cath & $-119.6^{*}$ & $-121.0^{* * *}$ & $-120.6^{* * *}$ & $-134.6^{* *}$ & $-139.5^{* * *}$ & $-135.4^{* * *}$ \\
& $(64.3)$ & $(22.4)$ & $(22.5)$ & $(67.6)$ & $(22.9)$ & $(23.0)$ \\
\hline Pop controls & & & & yes & yes & yes \\
Year effects & yes & yes & yes & yes & yes & yes \\
N & 14427 & 14427 & 14427 & 14427 & 14427 & 14427 \\
R2 & 0.10 & & 0.18 & 0.10 & & 0.18 \\
\hline
\end{tabular}

Notes: Significance levels: ${ }^{*} p<0.10,{ }^{* *} p<0.05,{ }^{* * *} p<0.01$. Robust standard errors in parentheses. The table shows the results from a difference-in-difference regression analysis. The outcome variable is yearly total expenditures per capita. The parameter of interest is the interaction between a dummy indicating that the observation is post 1989 and a dummy indicating that the municipality has a plurality of Catholics. The first three columns present regressions in which we only control for year fixed effects while we include detailed population controls in the latter three specifications. In columns 1 and 4 we use simple OLS, in 2 and 5 we specify a random effects model and in 3 and 6 we include municipality fixed effects. Source: Own calculations. 
Table V: Difference-in-difference-in-difference results in total spending

\begin{tabular}{|c|c|c|c|}
\hline & \multicolumn{3}{|c|}{ Comparision of big to small towns } \\
\hline & OLS & $\mathrm{RE}$ & $\mathrm{FE}$ \\
\hline & 1 & 2 & 3 \\
\hline \multicolumn{4}{|c|}{ Panel 1: Comparing high to low concentrated towns } \\
\hline $\begin{array}{l}\text { Interaction } \\
\text { Post } 89 * \text { high } \mathrm{HHI} * \text { Big town }\end{array}$ & $\begin{array}{c}-166.7^{* * * *} \\
(53.9)\end{array}$ & $\begin{array}{l}-177.5^{* * *} \\
\quad(26.2)\end{array}$ & $\begin{array}{c}-167.9^{* * *} \\
(26.3)\end{array}$ \\
\hline $\begin{array}{l}\mathrm{N} \\
\mathrm{R} 2\end{array}$ & $\begin{array}{c}46713 \\
0.14\end{array}$ & 46713 & $\begin{array}{c}46713 \\
0.23\end{array}$ \\
\hline \multicolumn{4}{|c|}{ ring Catholic to non-Catholic town } \\
\hline $\begin{array}{l}\text { Interaction } \\
\text { Post } 89 * \text { Cath } * \text { Big town }\end{array}$ & $\begin{array}{c}-146.1^{* * *} \\
\quad(49.9)\end{array}$ & $\begin{array}{c}-161.8^{* * *} \\
(25.0)\end{array}$ & $\begin{array}{c}-156.0^{* * *} \\
(25.0)\end{array}$ \\
\hline $\begin{array}{l}\mathrm{N} \\
\mathrm{R} 2\end{array}$ & $\begin{array}{c}46713 \\
0.14\end{array}$ & 46713 & $\begin{array}{c}46713 \\
0.23\end{array}$ \\
\hline
\end{tabular}

Notes: Significance levels: ${ }^{*} p<0.10,{ }^{* *} p<0.05,{ }^{* * *} p<0.01$. Robust standard errors in parentheses. The table highlights the results from a difference-in-difference-in-difference regression analysis. The outcome variable is yearly total expenditures per capita. In addition to the comparision between pre- and post-1989 and the measure of religious heterogeneity (HHI in the upper panel or a dummy indicating Catholic plurality in the lower panel), we add an indicator equal to one for towns with more than 4000 inhabitants, Bigtown: i.e. the towns which actually saw substantial migration. Column 1 presents OLS estimates, while columns 2 and 3 estimate random effect and fixed effect models, respectively. All regressions include year fixed effects as well as detailed population controls. Source: Own calculations. 
Figure II: Marginal effect of Catholic religion on local identification

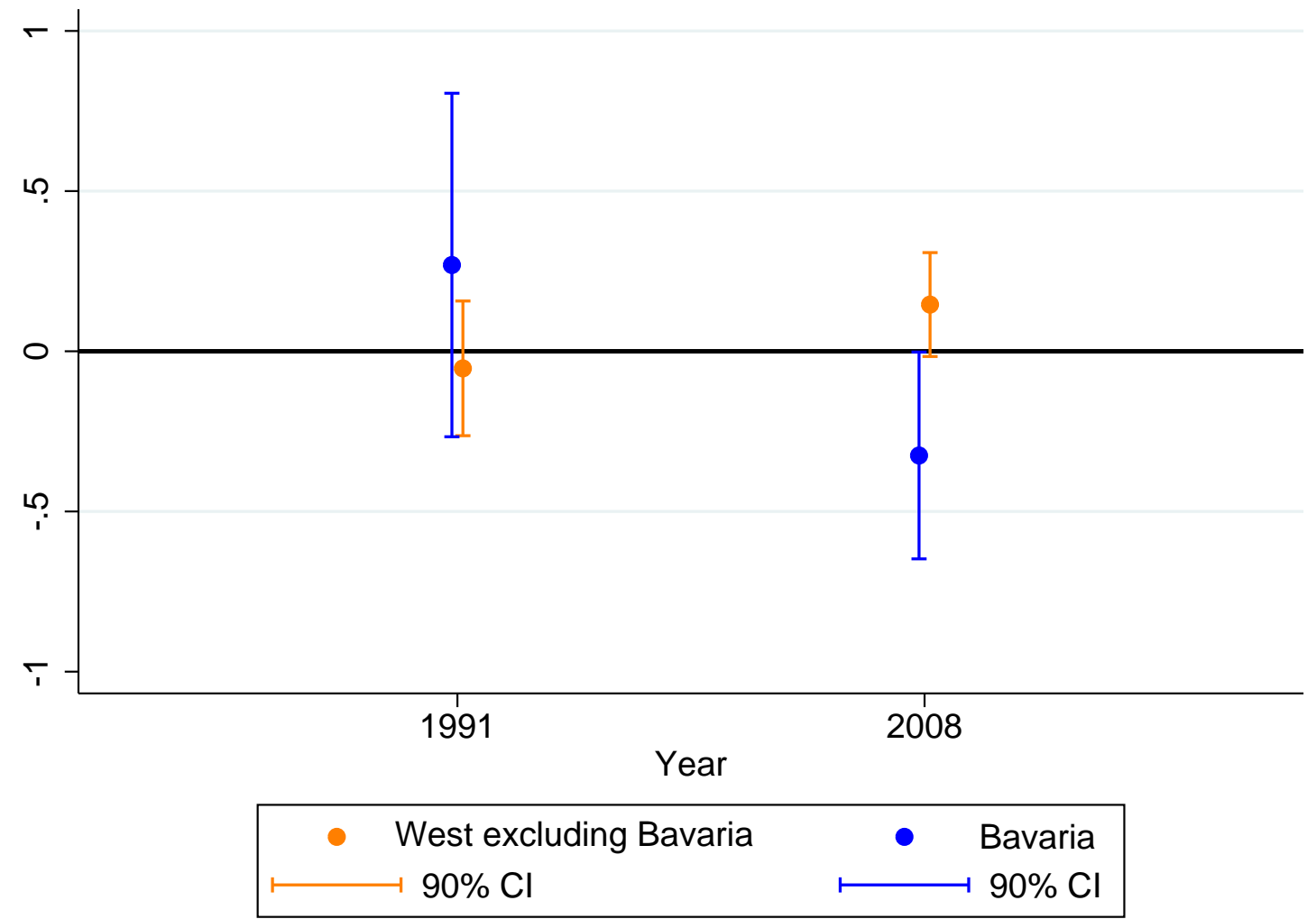

Notes: The figure depicts the result of two ordered logit regressions, one based on individuals living in Bavaria (dark-grey dots) and one based on individuals in all West-German states excluding Bavaria (light-grey dots). The dependent variable is social identification to one's town measured on a four-point scale ('strong attachment' (4) to 'no attachment' (1)). The variable of interest is an indicator for Catholics, and the dots in the figure reflect the marginal effect of this variable on social identification (with the whiskers representing 90 percent confidence intervals). Controls for an individual's income level, education level, political leaning and town size included in both model. Source: Own calculations. 
Table VI: Robustness tests I

\begin{tabular}{|c|c|c|c|c|c|c|}
\hline & \multicolumn{6}{|c|}{ FE estimation including population controls } \\
\hline & $\begin{array}{l}\text { US base } \\
\text { closures }\end{array}$ & Distance & $\begin{array}{c}\text { Exclude } \\
\text { two regions }\end{array}$ & $\begin{array}{l}\text { Regional } \\
\text { trends }\end{array}$ & $\begin{array}{r}\text { Pop } \\
\text { Above median }\end{array}$ & $\begin{array}{l}\text { rowth } \\
\text { Below median }\end{array}$ \\
\hline & 1 & 2 & 3 & 4 & 5 & 6 \\
\hline & \multicolumn{6}{|c|}{ Panel 1: Comparing high to low concentration towns } \\
\hline \multirow[t]{2}{*}{ Post $89 *$ high HHI } & $\begin{array}{c}-135.3^{* * *} \\
(22.4)\end{array}$ & $\begin{array}{c}-154.4^{* * *} \\
(22.3)\end{array}$ & $\begin{array}{c}-137.3^{* * *} \\
(28.4)\end{array}$ & $\begin{array}{c}-138.9^{* * *} \\
(26.5)\end{array}$ & $\begin{array}{c}-214.7^{* * *} \\
(44.9)\end{array}$ & $\begin{array}{c}-91.4^{* * *} \\
(18.7)\end{array}$ \\
\hline & \multicolumn{6}{|c|}{ Panel 2: Comparing Catholic to non-Catholic towns } \\
\hline $\begin{array}{l}\text { Interaction } \\
\text { Post } 89 * \text { Cath }\end{array}$ & $\begin{array}{c}-170.1^{* * *} \\
(24.2)\end{array}$ & $\begin{array}{c}-179.1^{* * *} \\
(23.4)\end{array}$ & $\begin{array}{c}-135.7^{* * *} \\
(26.8)\end{array}$ & $\begin{array}{c}-182.3^{* * *} \\
(28.4)\end{array}$ & $\begin{array}{c}-247.9^{* * *} \\
(48.5)\end{array}$ & $\begin{array}{c}-91.4^{* * *} \\
(19.1)\end{array}$ \\
\hline $\begin{array}{l}\text { Pop controls } \\
\text { Year effects } \\
\mathrm{N}\end{array}$ & $\begin{array}{c}\text { yes } \\
\text { yes } \\
13949\end{array}$ & $\begin{array}{c}\text { yes } \\
\text { yes } \\
14427\end{array}$ & $\begin{array}{c}\text { yes } \\
\text { yes } \\
11263\end{array}$ & $\begin{array}{c}\text { yes } \\
\text { yes } \\
14427\end{array}$ & $\begin{array}{c}\text { yes } \\
\text { yes } \\
6659\end{array}$ & $\begin{array}{c}\text { yes } \\
\text { yes } \\
7768\end{array}$ \\
\hline \multicolumn{7}{|c|}{$\begin{array}{l}\text { Notes: Significance levels: }{ }^{*} p<0.10,{ }^{* *} p<0.05,{ }^{* *} p<0.01 \text {. Robust standard errors in parentheses. The table presents a } \\
\text { number of robustness tests for the two difference-in-difference regression analyses above. The outcome variable is again yearly } \\
\text { total expenditures per capita. In panel } 1 \text {, we test the robustness of the approach in which we compare ex ante homogeneous } \\
\text { and ex ante heterogenous municipalities (based on the HHI) before and after } 1989 \text {, while in panel } 2 \text { we compare ex ante } \\
\text { Catholic versus non-Catholic towns over time. In column } 1 \text {, we test whether the closure of US military bases in Bavaria } \\
\text { affects our results, by excluding the } 23 \text { municipalities which saw post-unification closures of military bases. In column } 2 \text {, we } \\
\text { include a variable which measures the distance to the next local big center of economic activity (county-free city). In column } \\
3 \text {, we test for changes if we exclude the two regions to the north-east of Bavaria (Oberpfalz and Niederbayern) which may } \\
\text { have received particularly high subsidies before reunification. In column } 4 \text {, we include regional dummies and regional time } \\
\text { trends for each of the } 7 \text { Bavarian regions (Bezirke). Finally, in column } 5 \text { and } 6 \text {, we re-run the analysis for two subsets of } \\
\text { the data. In column } 5 \text {, we estimate the effect only from towns which saw above median growth rates in population during } \\
\text { the } 1995-2005 \text { period. In column } 6 \text {, we do the opposite and focus on those towns with below-median growth. Source: Own } \\
\text { calculations. }\end{array}$} \\
\hline
\end{tabular}


Table VII: Robustness tests II

\begin{tabular}{|c|c|c|c|c|c|c|}
\hline & \multicolumn{6}{|c|}{ FE estimation including population controls } \\
\hline & \multicolumn{2}{|c|}{ Alter. pop thres } & \multicolumn{2}{|c|}{ leaving out years } & \multicolumn{2}{|c|}{ Alter. distr. threshold } \\
\hline & 3000 & 5000 & $\neg ' 89$ & $\neg ' 89,90$ & Alt 1 & Alt 2 \\
\hline & 1 & 2 & 3 & 4 & 5 & 6 \\
\hline \multicolumn{7}{|c|}{ ino hiorh } \\
\hline $\begin{array}{l}\text { Interaction } \\
\text { Post } 89 * \text { high } \mathrm{HHI}\end{array}$ & $\begin{array}{c}-84.5^{* * *} \\
(16.7)\end{array}$ & $\begin{array}{c}-111.8^{* * *} \\
(25.8)\end{array}$ & $\begin{array}{c}-95.5^{* * *} \\
(22.3)\end{array}$ & $\begin{array}{c}-98.5^{* * *} \\
(22.7)\end{array}$ & $\begin{array}{c}-94.6^{* * *} \\
(22.6)\end{array}$ & $\begin{array}{c}-69.3^{* * *} \\
(23.9)\end{array}$ \\
\hline \multirow[b]{2}{*}{$\begin{array}{l}\text { Interaction } \\
\text { Post } 89 * \text { Cath }\end{array}$} & \multicolumn{5}{|c|}{ Panel 2: Comparing Catholic to non-Catholic towns } & \\
\hline & $\begin{array}{c}-105.9^{* * *} \\
(18.5)\end{array}$ & $\begin{array}{c}-132.0^{* * *} \\
(27.5)\end{array}$ & $\begin{array}{c}-137.8^{* * *} \\
(24.7)\end{array}$ & $\begin{array}{c}-146.2^{* * *} \\
(25.1)\end{array}$ & $\begin{array}{c}-134.8^{* * *} \\
(22.6)\end{array}$ & $\begin{array}{c}-119.4^{* * *} \\
(21.8)\end{array}$ \\
\hline Pop controls & yes & yes & yes & yes & yes & yes \\
\hline Year effects & yes & yes & yes & yes & yes & yes \\
\hline $\mathrm{N}$ & 19959 & 10874 & 13849 & 13253 & 14427 & 14427 \\
\hline \multicolumn{7}{|c|}{$\begin{array}{l}\text { Notes: Significance levels: }{ }^{*} p<0.10,{ }^{*} p<0.05,{ }^{* *} p<0.01 \text {. Robust standard errors in parentheses. The } \\
\text { table presents a number of robustness tests for the two difference-in-difference regression analyses above. The } \\
\text { outcome variable is again yearly total expenditures per capita. In panel } 1 \text {, we test the robustness of the approach } \\
\text { in which we compare ex ante homogeneous and ex ante heterogenous municipalities (based on the HHI) before } \\
\text { and after } 1989 \text {, while in panel } 2 \text { we compare ex ante Catholic versus non-Catholic towns over time. In columns } 1 \\
\text { and } 2 \text {, we change the population cutoff from } 4000 \text { inhabitants to } 3000 \text { and } 5000 \text { respectively. In columns } 3 \text { and } 4 \text {, } \\
\text { we exclude the years } 1989 \text { and } 1990 \text {. Finally, in columns } 5 \text { and } 6 \text {, we specify alternative thresholds for the cutoff } \\
\text { on the religious heterogeneity distribution. In the upper panel, we use the } 60 \text { th and } 70 \text { th percentiles of the HHI } \\
\text { distribution in } 1987 \text { instead of the median. In the lower panel, we define a Catholic municipality not by Catholic } \\
\text { plurality but by the share of Catholics in } 1987 \text { (more than } 50 \text { percent in Alt } 1 \text {, and more then } 66.6 \text { percent in } \\
\text { Alt } 2 \text { ). All regressions include year and municipality fixed effects as well as detailed population controls. Source: } \\
\text { Own calculations. }\end{array}$} \\
\hline
\end{tabular}


Table VIII: Robustness III Diff-in-Diff with Catholic plurality for concentrated towns only

\begin{tabular}{lcccccc}
\hline \hline & \multicolumn{7}{c}{ Total spending } \\
\cline { 2 - 7 } & OLS & RE & FE & OLS & RE & FE \\
\hline Interaction & 1 & 2 & 3 & 4 & 5 & 6 \\
Post 89 ${ }^{*}$ Cath & $-218.0^{*}$ & $-213.8^{* * *}$ & $-213.1^{* * *}$ & $-218.6^{*}$ & $-216.0^{* * *}$ & $-218.8^{* * *}$ \\
& $(118.0)$ & $(30.2)$ & $(30.2)$ & $(117.8)$ & $(30.2)$ & $(30.5)$ \\
\hline Pop controls & & & & yes & yes & yes \\
Year effects & yes & yes & yes & yes & yes & yes \\
N & 12308 & 12308 & 12308 & 12308 & 12308 & 12308 \\
R2 & 0.11 & & 0.16 & 0.11 & & 0.17 \\
\hline
\end{tabular}

Notes: Significance levels: ${ }^{*} p<0.10,{ }^{* *} p<0.05,{ }^{* * *} p<0.01$. Robust standard errors in parentheses. The table shows the results from a difference-in-difference regression analysis. The outcome variable is yearly total expenditure per capita. The parameter of interest is the interaction between a dummy indicating that the observation is post 1989 and a dummy indicating that the municipality has a plurality of Catholic. In contrast to above, we have limited the data set to include only those non-Catholic towns which are most religiously concentrated (i.e. the 92 out of 183 municipalities which are most concentrated). The first three columns present regressions in which we control only for year fixed effects, while we include detailed population controls in the latter three specifications. In columns 1 and 4 we use simple OLS, in 2 and 5 we specify a random effects model and in 3 and 6 we include municipality fixed effects. Source: Own calculations. 
Table IX: Diff-in-Diff comparing election outcomes 1984-2002

\begin{tabular}{|c|c|c|c|c|c|c|}
\hline & \multicolumn{6}{|c|}{ Electoral outcomes } \\
\hline & \multicolumn{2}{|c|}{ CSU } & \multicolumn{2}{|c|}{ SPD } & \multicolumn{2}{|c|}{ Abs Maj } \\
\hline & $\mathrm{VS}$ & Seats & VS & Seats & $\mathrm{CSU}$ & All \\
\hline & 1 & 2 & 3 & 4 & 5 & 6 \\
\hline & \multicolumn{6}{|c|}{ Panel 1: Comparing high to low concentration towns } \\
\hline $\begin{array}{l}\text { Interaction } \\
\text { Post } 89 * \text { high HHI }\end{array}$ & $\begin{array}{c}-0.012^{* *} \\
(0.006)\end{array}$ & $\begin{array}{c}-0.284^{* *} \\
(0.136)\end{array}$ & $\begin{array}{c}0.013^{* * *} \\
(0.005)\end{array}$ & $\begin{array}{l}0.203^{*} \\
(0.112)\end{array}$ & $\begin{array}{c}-0.084^{* *} \\
(0.037)\end{array}$ & $\begin{array}{l}-0.045 \\
(0.039)\end{array}$ \\
\hline \multirow[t]{2}{*}{$\mathrm{R} 2$} & $\begin{array}{l}2489 \\
0.177\end{array}$ & $\begin{array}{l}2489 \\
0.179\end{array}$ & $\begin{array}{l}2489 \\
0.203\end{array}$ & $\begin{array}{l}2489 \\
0.180 \\
\end{array}$ & $\begin{array}{l}2489 \\
0.097 \\
\end{array}$ & $\begin{array}{l}2489 \\
0.099\end{array}$ \\
\hline & \multicolumn{6}{|c|}{ Panel 2: Comparing Catholic to non-Catholic towns } \\
\hline $\begin{array}{l}\text { Interaction } \\
\text { Post } 89 * \text { Cath }\end{array}$ & $\begin{array}{c}-0.017^{* * *} \\
(0.005)\end{array}$ & $\begin{array}{c}-0.315^{* *} \\
(0.128)\end{array}$ & $\begin{array}{c}0.013^{* * *} \\
(0.004)\end{array}$ & $\begin{array}{c}0.291^{* * *} \\
(0.106)\end{array}$ & $\begin{array}{c}-0.097^{* * *} \\
(0.035)\end{array}$ & $\begin{array}{l}-0.054 \\
(0.036)\end{array}$ \\
\hline $\begin{array}{l}\mathrm{N} \\
\mathrm{R} 2\end{array}$ & $\begin{array}{l}2489 \\
0.179\end{array}$ & $\begin{array}{l}2489 \\
0.179\end{array}$ & $\begin{array}{l}2489 \\
0.203\end{array}$ & $\begin{array}{l}2489 \\
0.182\end{array}$ & $\begin{array}{l}2489 \\
0.098\end{array}$ & $\begin{array}{l}2489 \\
0.099\end{array}$ \\
\hline
\end{tabular}

Notes: Significance levels: ${ }^{*} p<0.10,{ }^{* *} p<0.05,{ }^{* * *} p<0.01$. Robust standard errors in parentheses. The table shows the results from a difference-in-difference regression analysis on voting outcomes. In panel 1, the parameter of interest is the interaction between a dummy indicating that the observation is post 1989 and a dummy indicating that the municipality was relatively homogeneous in 1987 (the HHI on religion is above the median). In panel 2, the parameter of interest is instead the interaction between a post 1989 dummy and a dummy indicating that the municipality has a plurality of Catholics in 1987. Each column represents a different electoral outcome variable: (1) vote share of the CSU, (2) number of seats of the CSU, (3) vote share of the SPD, (4) seat share of the SPD, (5) probability of the CSU having an absolute majority, (6) probability of any party having an absolute majority. For each outcome, we estimated a separate fixed effects regression including detailed population controls and well as year fixed effects. Source: Own calculations. 


\section{A Appendix - additional tables and figures}

Figure III: Spatial distribution of homogeneous and heterogenous towns
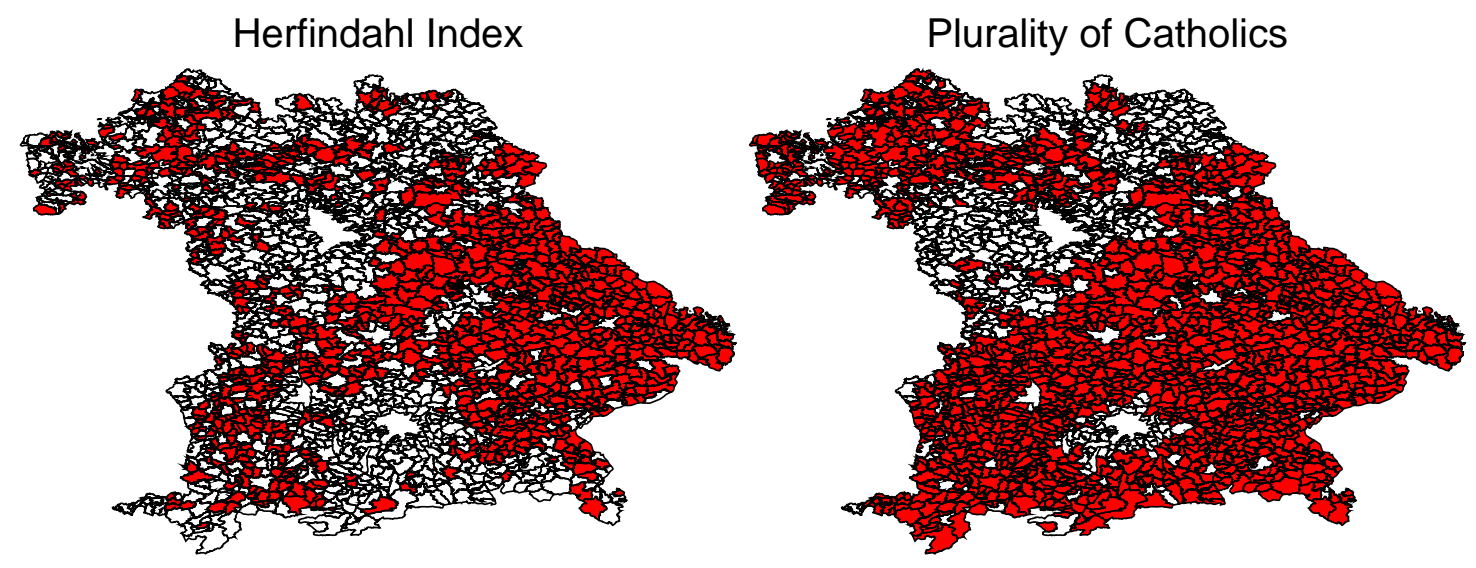

Notes: These maps show the spatial dispersion of homogeneous and heterogenous towns in Bavaria. The map on the left uses the Herfindahl index to split the sample into two (observations with a HHI below or above the median). Highly homogeneous towns are indicated in the darker color. The map to the right shows the map for the sample slip between towns with a plurality of Catholics and those without such plurality. Source: Own calculations. 
Figure IV: Yearly changes in population figures in subgroups for 1984-2005 (in percent)
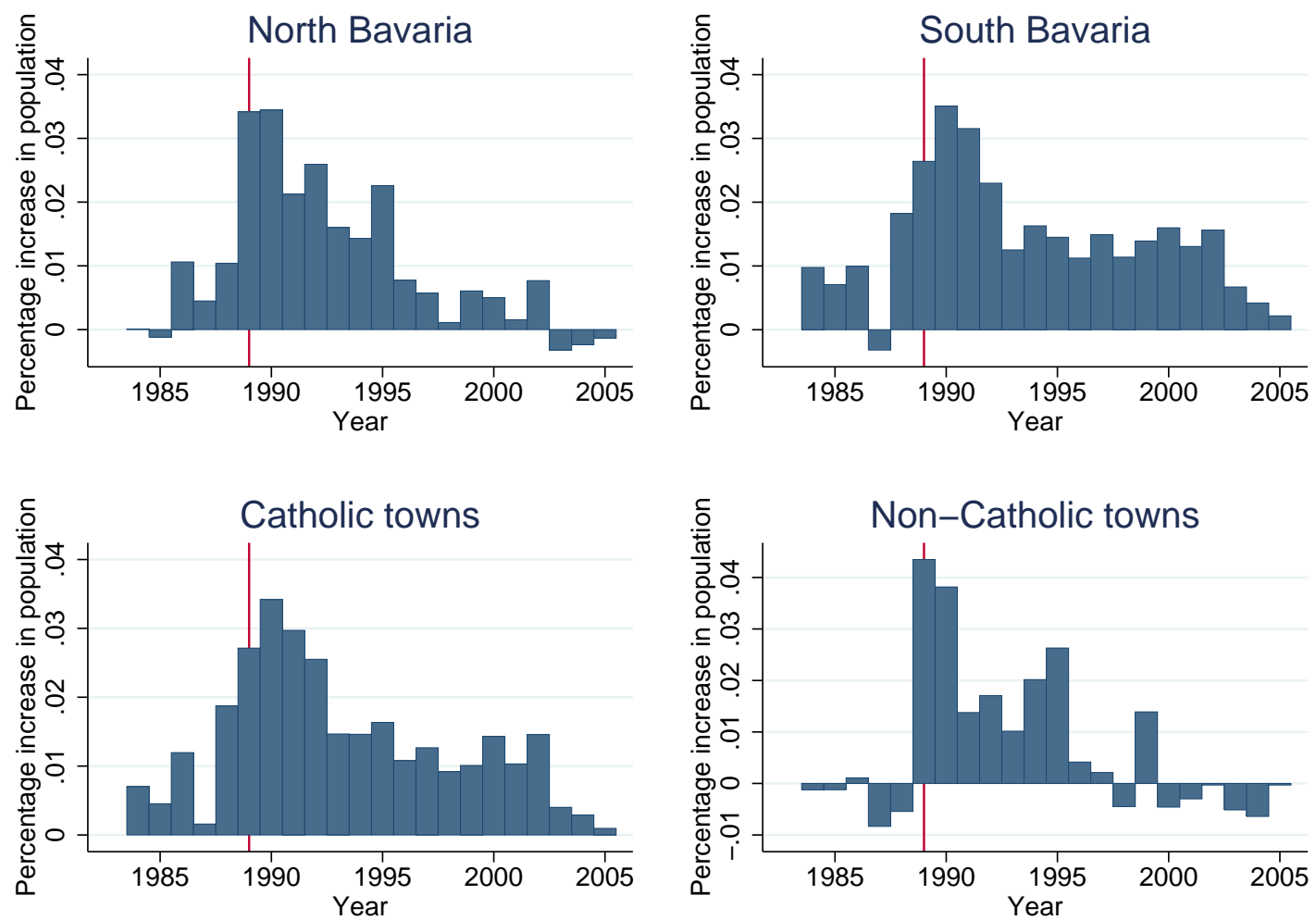

Notes: This figure focuses on population growth (in percent) in four subgroups. The two upper panels represent population changes across Bavaria's northern and southern regions, as coded by administrative borders. The north is comprised by Unter-, Ober- and Mittelfranken as well as Oberpfalz. The south includes all muncipalities of the districts of Schwaben, Ober- and Niederbayern. The lower two panels are concerned with municipalities' religious composition. We split the sample between municipalities with Catholic and non-Catholic plurality. Note that 1987 differs from other years because there was a general census in which population numbers were corrected. The vertical line indicates the year 1989 in which the process of reunification started, first with open migration of East Germans through Hungary and finally the fall of the Wall in November 1989. As the graph illustrates, the wave of migration in the ensuing years was substantial in every subgroup. Source: Own calculations. 
Figure V: Trends in expenditures from 1984-2005 (by Catholic vs. non-Catholic towns)
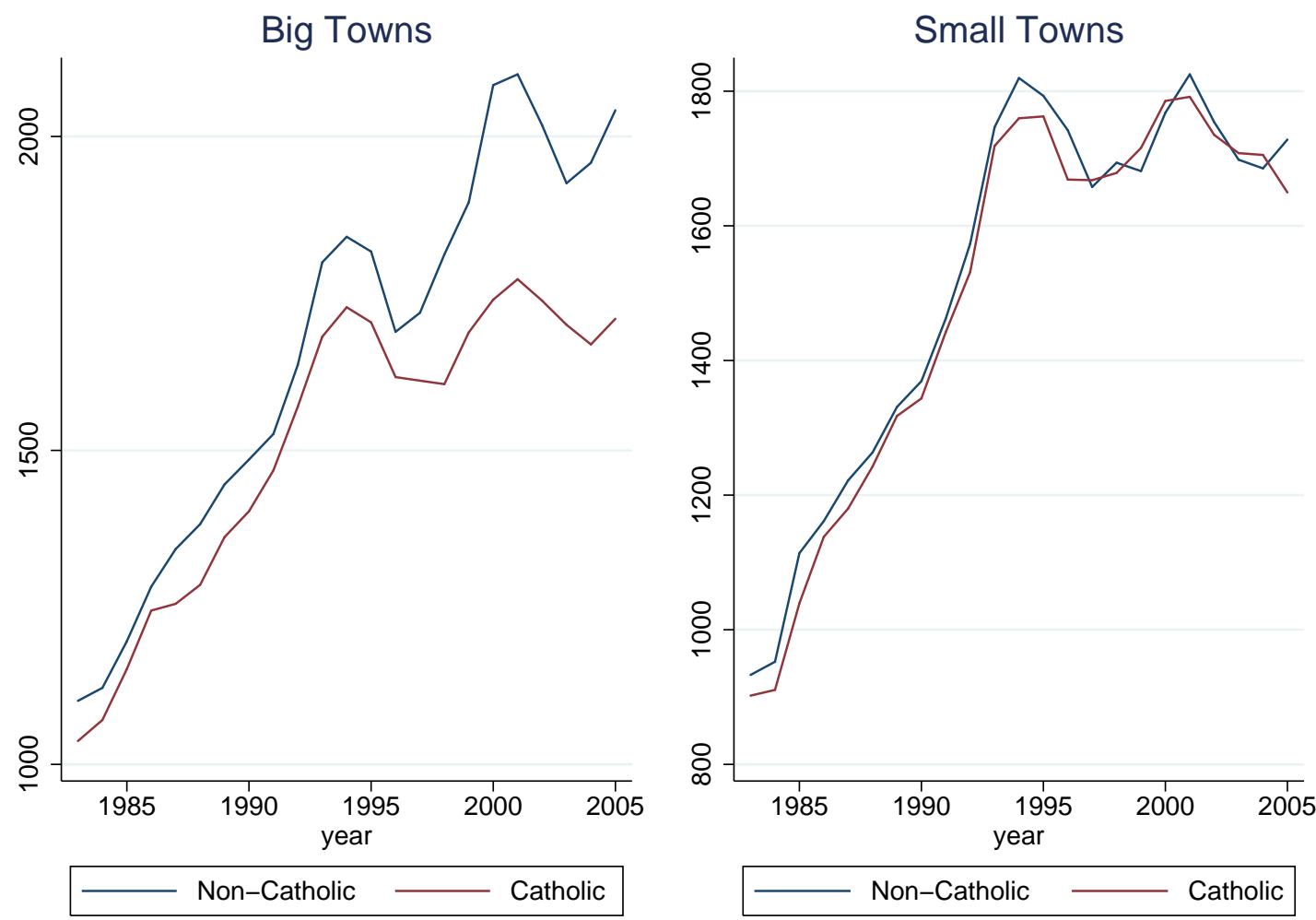

Notes: This graph illustrates the trend in total per capita spending in Bavarian municipalities with more than 4000 inhabitants (left panel) and with fewer than 4000 inhabitants. We show the measures by differentiating between towns with Catholic plurality and non-Catholic towns. Source: Own calculations. 
Figure VI: Robustness: Trends in share of unemployed from 1998-2004 (by Catholic vs. non-Catholic towns)

\section{Share of unemployed}

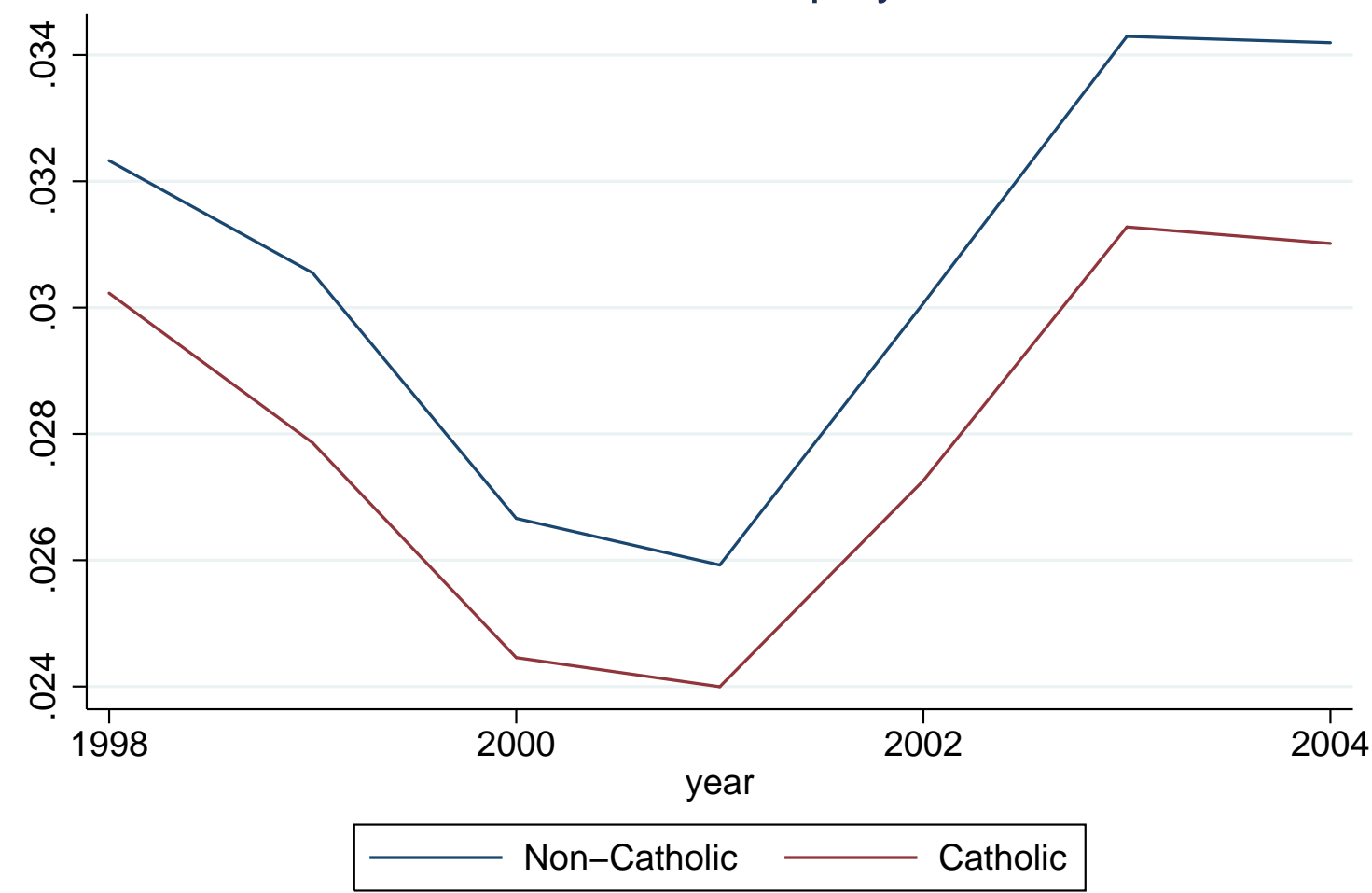

Notes: This graph illustrates the trend in the share of unemployed inhabitants (number of unemployed divided by the population) in Bavarian municipalities with more than 4000 inhabitants. We show the measure by differentiating between towns with and without a Catholic plurality in 1987. Data on unemployment before 1998 are not available on the municipal level. Data after 2005 are not comparable since there is a break in how those numbers are reported on the municipal level by the Bundesagentur für Arbeit.Source: Own calculations. 
Table X: Descriptive statistics on fiscal outcome data

\begin{tabular}{lrrrrrr}
\hline \hline \multicolumn{1}{c}{ Variable } & Obs & \multicolumn{1}{c}{ Mean } & Std. dev & Median & Min & \multicolumn{1}{c}{ Max } \\
\hline Total spending & 46711 & 1517.39 & 771.06 & 1407.15 & 0 & 36617.25 \\
Spending on personel & 46711 & 193.39 & 93.04 & 181.55 & 0 & 3145.44 \\
Investment spending & 46712 & 399.38 & 332.02 & 325.09 & 0 & 18927.94 \\
\hline Revenue from taxes & 46711 & 429.06 & 367.97 & 385.13 & 0 & 55939.68 \\
Revenue from fees & 46710 & 120.08 & 120.64 & 92.74 & 0 & 4798.72 \\
\hline Prop tax A multiplier & 46713 & \multicolumn{1}{c}{316} & 58 & 300 & 140 & 800 \\
Prop tax B multiplier & 46713 & 309 & 49 & 300 & 150 & 800 \\
Trade tax multiplier & 46712 & 317 & 22 & 320 & 230 & 520 \\
\hline
\end{tabular}

Notes: The table shows descriptive statistics for the fiscal outcome data in the analysis, pooling the information from all 2031 municipalities over 23 years. All information on spending and revenue is per capita and year. We present information on the number of observations, the mean, standard deviation, median as well as min and max of all variables. In the top panel, we show the information in total spending as well as the subgroups spending on personel and investment spending. In the middle panel, we present the data on revenues from taxes and fees. Note that we have deleted very few observations which had obvious mistakes in the data (negative spending or revenues). In the lower rows, we show the statistics for the tax multiplier set by the municipalities, which is the local decision variable with respect to taxation. Those multipliers are arguments in the tax formula for the local property and business (trade) taxes. They are bounded between 0-800 (in the period of observation). Source: Own calculations. 
Table XI: Diff-in-Diff for spending and revenue categories

\begin{tabular}{|c|c|c|c|c|c|c|}
\hline & \multicolumn{6}{|c|}{ FE estimation including population controls } \\
\hline & \multicolumn{3}{|c|}{ Spending categories } & \multicolumn{3}{|c|}{ Revenue categories } \\
\hline & Pers & Operative & Invest & Taxes & Fees & Grants \\
\hline & 1 & 2 & 3 & 4 & 5 & 6 \\
\hline & \multicolumn{6}{|c|}{ Panel 1: Comparing high to low concentration towns } \\
\hline $\begin{array}{l}\text { Interaction } \\
\text { Post } 89 * \text { high HHI }\end{array}$ & $\begin{array}{c}-11.2^{* * *} \\
(1.9)\end{array}$ & $\begin{array}{c}-10.8^{* * * *} \\
(2.1)\end{array}$ & $\begin{array}{l}-4.1 \\
(8.1)\end{array}$ & $\begin{array}{c}-53.8^{* * * *} \\
(7.7)\end{array}$ & $\begin{array}{c}-14.7^{* * *} \\
(3.1)\end{array}$ & $\begin{array}{c}2.9 \\
(3.7)\end{array}$ \\
\hline & \multicolumn{6}{|c|}{ Panel 2: Comparing Catholic to non-Catholic towns } \\
\hline $\begin{array}{l}\text { Interaction } \\
\text { Post } 89 * \text { Cath }\end{array}$ & $\begin{array}{c}-6.1^{* * *} \\
(2.0)\end{array}$ & $\begin{array}{c}-8.6^{* * *} \\
(2.2)\end{array}$ & $\begin{array}{l}-13.9 \\
(8.5)\end{array}$ & $\begin{array}{c}-63.1^{* * *} \\
(8.0)\end{array}$ & $\begin{array}{c}-8.5^{* * *} \\
(3.2)\end{array}$ & $\begin{array}{c}0.1 \\
(3.9)\end{array}$ \\
\hline Pop controls & yes & yes & yes & yes & yes & yes \\
\hline Year effects & yes & yes & yes & yes & yes & yes \\
\hline $\mathrm{N}$ & 14427 & 14427 & 14427 & 14427 & 14427 & 14427 \\
\hline
\end{tabular}

Notes: Significance levels: ${ }^{*} p<0.10,{ }^{* *} p<0.05,{ }^{* * *} p<0.01$. Robust standard errors in parentheses. The table shows the results from two difference-in-difference regression analyses. The outcome variables are indicated above (different expenditure and revenue categories). In panel 1, the parameter of interest is the interaction between a dummy indicating that the observation is post 1989 and a dummy indicating that the municipality was relatively homogeneous in 1987 (the HHI on religion is above the median). In panel 2, the parameter of interest is instead the interaction between a post 1989 dummy and a dummy indicating that the municipality has a plurality of Catholics in 1987. All regressions include year and municipality fixed effects as well as detailed population controls. Source: Own calculations. 
Table XII: Diff-in-Diff for local tax setting

\begin{tabular}{|c|c|c|c|}
\hline & \multicolumn{3}{|c|}{ FE estimation including population controls } \\
\hline & Property tax A & Property tax B & Trade tax \\
\hline & 1 & 2 & 3 \\
\hline & \multicolumn{3}{|c|}{ Panel 1: Comparing high to low concentration towns } \\
\hline $\begin{array}{l}\text { Interaction } \\
\text { Post } 89 * \text { high } \mathrm{HHI}\end{array}$ & $\begin{array}{c}-3.69^{* * *} \\
(0.58)\end{array}$ & $\begin{array}{c}-4.61^{* * *} \\
(0.56)\end{array}$ & $\begin{array}{c}-2.04^{* * *} \\
(0.36)\end{array}$ \\
\hline & \multicolumn{3}{|c|}{ Panel 2: Comparing Catholic to non-Catholic towns } \\
\hline $\begin{array}{l}\text { Interaction } \\
\text { Post } 89 * \text { Cath }\end{array}$ & $\begin{array}{l}-0.9 \\
(0.6)\end{array}$ & $\begin{array}{c}-1.9^{* * *} \\
(0.6)\end{array}$ & $\begin{array}{l}-0.4 \\
(0.4)\end{array}$ \\
\hline $\begin{array}{l}\text { Pop controls } \\
\text { Year effects } \\
\mathrm{N}\end{array}$ & $\begin{array}{c}\text { yes } \\
\text { yes } \\
14427\end{array}$ & $\begin{array}{c}\text { yes } \\
\text { yes } \\
14427\end{array}$ & $\begin{array}{c}\text { yes } \\
\text { yes } \\
14427\end{array}$ \\
\hline
\end{tabular}

Notes: Significance levels: ${ }^{*} p<0.10,{ }^{* *} p<0.05,{ }^{* * *} p<0.01$. Robust standard errors in parentheses. The table shows the results from two difference-in-difference regression analyses. The outcome variables are the tax rate multipliers on the three local taxes (property tax A, property tax B and trade tax). In panel 1, the parameter of interest is the interaction between a dummy indicating that the observation is post 1989 and a dummy indicating that the municipality was relatively homogeneous in 1987 (the HHI on religion is above the median). In panel 2, the parameter of interest is instead the interaction between a post 1989 dummy and a dummy indicating that the municipality has a plurality of Catholics in 1987. All regressions include year and municipality fixed effects as well as detailed population controls. Source: Own calculations. 
Table XIII: Comparing detailed expenditures (1998-2006)

\begin{tabular}{|c|c|c|c|c|}
\hline & \multicolumn{4}{|c|}{ Comparision of Catholic and non-Catholic towns } \\
\hline & \multicolumn{2}{|c|}{$>=4,000$ citizen } & \multicolumn{2}{|c|}{$<4,000$ citizen } \\
\hline & OLS & OLS & OLS & OLS \\
\hline & 1 & 2 & 3 & 3 \\
\hline Spending on administration & $\begin{array}{c}-15.940^{* * *} \\
(3.819)\end{array}$ & $\begin{array}{c}-16.084^{* * *} \\
(3.997)\end{array}$ & $\begin{array}{l}-2.931 \\
(4.132)\end{array}$ & $\begin{array}{l}-5.354 \\
(3.551)\end{array}$ \\
\hline Spending on public order & $\begin{array}{c}-5.611^{* * *} \\
(2.113)\end{array}$ & $\begin{array}{l}-3.623 \\
(2.222)\end{array}$ & $\begin{array}{c}1.139 \\
(1.388)\end{array}$ & $\begin{array}{c}1.113 \\
(1.385)\end{array}$ \\
\hline Spending on public utilies & $\begin{array}{c}-52.696^{* *} \\
(23.209)\end{array}$ & $\begin{array}{c}-65.400^{* * *} \\
(24.349)\end{array}$ & $\begin{array}{c}-33.478^{* * *} \\
(8.841)\end{array}$ & $\begin{array}{c}-33.508^{* * *} \\
(8.855)\end{array}$ \\
\hline Spending on cultural programs & $\begin{array}{c}-15.293^{* * *} \\
(3.460)\end{array}$ & $\begin{array}{c}-8.962^{* * *} \\
(3.301)\end{array}$ & $\begin{array}{l}-1.047 \\
(1.200)\end{array}$ & $\begin{array}{l}-1.249 \\
(1.163)\end{array}$ \\
\hline Spending on adult education & $\begin{array}{c}-6.694^{* * *} \\
(1.209)\end{array}$ & $\begin{array}{c}-4.799^{* * *} \\
(1.148)\end{array}$ & $\begin{array}{l}-0.494 \\
(0.350)\end{array}$ & $\begin{array}{l}-0.526 \\
(0.323)\end{array}$ \\
\hline Spending on churches & $\begin{array}{c}0.684^{* *} \\
(0.297)\end{array}$ & $\begin{array}{l}0.543^{*} \\
(0.291)\end{array}$ & $\begin{array}{c}0.537 \\
(0.529)\end{array}$ & $\begin{array}{c}0.611 \\
(0.527)\end{array}$ \\
\hline Spending on public welfare programs & $\begin{array}{c}-18.808^{* * *} \\
(5.329)\end{array}$ & $\begin{array}{c}-15.653^{* * *} \\
(5.569)\end{array}$ & $\begin{array}{c}0.602 \\
(2.842)\end{array}$ & $\begin{array}{c}1.081 \\
(2.833)\end{array}$ \\
\hline Spending on elderly care & $\begin{array}{l}-2.246 \\
(2.930)\end{array}$ & $\begin{array}{l}-3.007 \\
(3.013)\end{array}$ & $\begin{array}{l}-0.243 \\
(3.890)\end{array}$ & $\begin{array}{l}-1.221 \\
(3.976)\end{array}$ \\
\hline Spending on child care & $\begin{array}{c}-10.085^{* *} \\
(4.068)\end{array}$ & $\begin{array}{c}-9.223^{* *} \\
(4.261)\end{array}$ & $\begin{array}{c}1.693 \\
(2.708)\end{array}$ & $\begin{array}{c}2.215 \\
(2.690)\end{array}$ \\
\hline $\mathrm{N}$ & 666 & 666 & 1365 & 1365 \\
\hline
\end{tabular}

Notes: Significance levels: ${ }^{*} p<0.10,{ }^{* *} p<0.05,{ }^{* * *} p<0.01$. Robust standard errors in parentheses. The table presents the results for detailed spending categories in the period 1998-2005. Each coefficient represents the output of a separate regression of the spending outcome variable on a dummy variable equal to one for municipalities with Catholic plurality in 1987. To reduce variability in the spending data, we have taken the mean in the spending category over the entire observation period 1998-2005. The respective outcome categories are given in the left column. In columns 1 and 2, we use data only for municipalities with more than 4000 inhabitants (which saw substantial migration), in columns 3 and 4 we use data on municipalities below 4000 inhabitants as a placebo. The results in columns 1 and 3 come from a simple OLS model in which we regress the spending category only on the Catholic dummy. In columns 2 and 4, we also carefully control for population size by including linear and squared terms as well as dummies for specific size groups. Source: Own calculations. 